\title{
Paths to Power in the Early Stage of Colonialism: An Archaeological Study of the Sultanate of Banten, Java, Indonesia, the Seventeenth to Early Nineteenth Century
}

\author{
(2) (2) \\ KAORU UEDA, SONNY C. WIBISONO, NANIEK HARKANTININGSIH, \\ AND CHEN SIAN LIM
}

\section{INTRODUCTION}

Southeast Asian port cities such as the Sultanate of Banten (mid-1500s through 1813) played a pivotal role in early modern global trade (Fig. 1). These urban communities were central to the region's political, economic, and cultural development. Initially, Europeans were mere participants in this well-established trade network but eventually colonized most of the region (Reid 1988, 2:270-281; Stark 2014). Although archaeologists have long recognized Banten as playing an important role in the region (Guillot 1993; Miksic 1989; Ota 2006), their interpretations have largely been drawn from monumental architecture and major historical events (Guillot et al. 1990; Michrob 1982). The lack of systematic archaeological data from the sultanate as well as the focus on Banten's past as a prosperous independent state (most likely the result of local anti-Dutch sentiments) has led archaeologists to neglect or misinterpret the sultanate's past during the period when the Dutch East India Company (a.k.a. Vereenigde Oost-Indische Compagnie or VOC) exercised political and economic control over this port city.

The archaeological study presented here aims to provide new data with which to shed light on the court life after the establishment of the sultanate's vassal status in 1682 until its official abolishment in 1813. This study is supplemented by historical and ethnographic records as well as archaeological data from the contemporaneous nearby VOC fort at Banten, primarily manned by Dutch (and a few German) soldiers (VOC 1733, 1780). As much as European and indigenous historical texts provide insight into the public activities of the sultans and their courts, more mundane daily

Kaoru Ueda is a post-doctoral researcher at the International Center for East Asian Archaeology and Cultural History, Department of Archaeology, Boston University. Sonny C. Wibisono is a member of the National Research Center of Archaeology of Indonesia. Naniek Harkantiningsih is a member of the National Research Center of Archaeology of Indonesia. Chen Sian Lim is affiliated with the Institute of Southeast Asian Studies (ISEAS) Archaeology Unit in Singapore. 


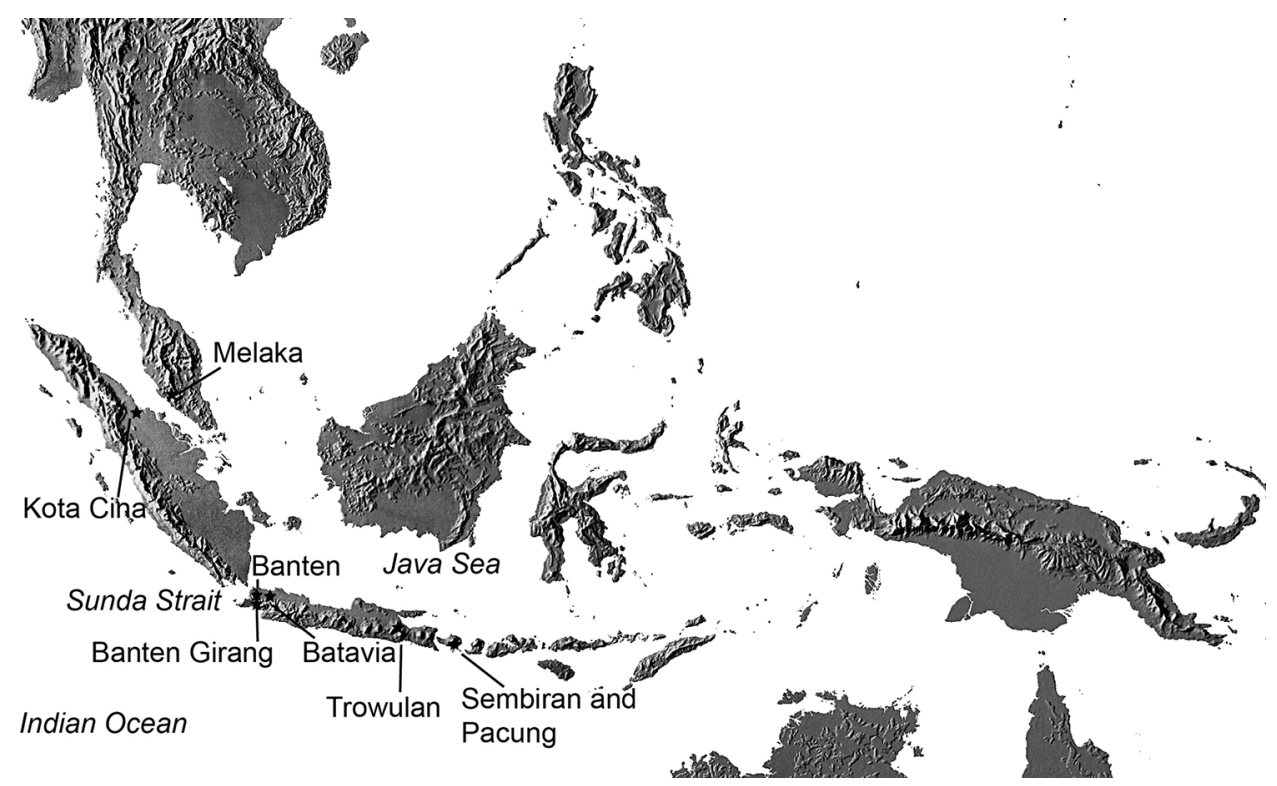

Fig. 1. Map of Southeast Asia, showing Banten, Banten Girang, Batavia (headquarters of the Dutch East India Company, present-day Jakarta), Melaka (Malacca), Trowulan, Kota Cina, Sembiran, and Pacung.

aspects of their lives within the palace precinct are underdocumented. The present archaeological research thus attempts to fill the gap in information available to Indonesian and international scholars regarding a major global trading center in early modern Island Southeast Asia.

The sultanate historically known as Bantam, located in northwest Java near the Sunda Strait, was one of the most important trading hubs in Southeast Asia from the sixteenth through the eighteenth century (Guillot 1993:90; Raffles 1830, 1:xx). Banten embraced Island Southeast Asia's long-standing tradition of long-distance maritime trade and pluralistic communities. When the Dutch arrived at Banten in 1596, they were among many foreign merchants who were eager to trade with the sultanate to gain a share in the lucrative pepper market (Bosma and Raben 2008:9; Lodewycksz [1598] 1997:141-142).

As recorded in official VOC documents and other published European descriptions of the sultan's public activities, feasting at Banten was highly ritualized. In the court of Banten in 1769, for instance, the Dutch traveler Stavorinus attended a banquet hosted by the sultan. At the royal banquet, he noted, the meals were served on the basis of political ranking. The nobles who were sitting on the rattan mat at the end of the hall could not eat until the diners at the main table had finished their meals. The fish leftovers were offered to the nobles along with boiled rice served in Chinese bowls. Their plates were quickly emptied "with continual eructations" as enthusiastic belching was "an etiquette of the court" for the guests to show their appreciation to the king for plentiful and tasty food (Stavorinus 1798:84-85).

However, the daily life of the sultan and his court within the palace precinct remained relatively underrecorded and understudied: high walls surrounded the sultan's residence to "render it impervious to the eyes of the curious" and death pen- 
alties were imposed on VOC soldiers who dared to scale these walls (Stavorinus 1798:66). By examining the daily aspects of court life, the present archaeological research aims to explore the processes of power transformation from the onset of VOC's political, military, and economic interventions in 1682 until the sultanate's abolishment in 1813. Particular attention is paid to food-related domains of prestige material culture, because food and beverage consumption is an integral part of ceremonies for status display and elite social interactions (Dietler 1990, 2001; Junker 1999: 9).

\section{GEOGRAPHY AND THE PATTERN OF POWER CONTROL IN BANTEN}

Past scholarship has shown that the power structure of Island Southeast Asia is intricately connected to its geography, both on the sea and the land. Network strategies (Blanton et al. 1996; Feinman et al. 2000) are particularly pertinent to explain the region's long-distance maritime orientation to obtain prestige goods with which to enhance power in local societies. As early as the late first millennium B.C., longdistance trade and cross-cultural interactions have been part of the social fabric of many port cities in this region (Reid 1988; Wade 2009), as archaeologically evidenced at the sites of Sembiran and Pacung in Bali, Indonesia (Ardika and Bellwood 1991; Ardika et al. 1997; Calo et al. 2015). Richard Blanton and his colleagues (1996:4) have proposed that participants linked through social connections spread over a large area to take advantage of differentiated access to marriage alliances, "exotic goods," and "specialized knowledge" acquired from distant places to further their power in the local societies. Although the realities are more complex and nuanced, the "network" mode of power tends to be distinct from the "corporate" mode, where wealth is more evenly distributed and power is derived from group association (Feinman et al. 2000).

While Island Southeast Asia has enjoyed extensive maritime networks, consolidating power on land has presented a challenge. Although it does not do justice to the diverse and vast area of Island Southeast Asia to generalize about the nature of power structures, scholars working here have increasingly recognized that the densely vegetated environment in many parts of the region has contributed to shaping the nature of power negotiations (Andaya 1992; Bellwood 2005; Boomgaard 2007; Junker 1998, 2001). Because centralized authority over diverse pockets of a population is difficult to achieve and maintain, they have argued that instability and fluidity of power and alliance coalitions, rather than territory-driven stable power structures, are some of the characteristics in this part of the world (Andaya 1992:405; Bellwood 2005:13; Boomgaard 2007:61; Geertz 1973:331-338; Junker 1998, 2001:283; Reid 1992: 460-463, 1993:157; Ricklefs 1981:15, 66; Wolters 1982).

Further implications of these geographical conditions are the relatively low population density and high population mobility (Junker 1998:292, 2010:283; Reid 1993 : 157). One distinct sociocultural trait associated with this population pattern is a fluid definition of territories and an emphasis on the control of labor instead of land. The way the local lords managed the land does not easily conform to the European definition of territories. Before the period of Dutch colonial rule, the elites in the island of Java did not have the same concept of private land ownership as Europeans did, and their military strength or wealth was measured not by the size of territory they controlled but by the human resources they could mobilize (Onghokham $2003: 157)$. 
Historical records highlight the fragmented and competitive political landscape in Java. As early as the late twelfth century, the Chinese customs official, Chau Ju-kua (a.k.a. Zhao Rugua 趙汝适, 1170-1228), who compiled trade and political observations about various places from Southeast Asia to the Middle East, recorded the contentious politics of Java with its many petty states packed next to one another (Chau 1911: 83). Java's political complexity continued, and was perhaps further exacerbated as long-distance trade expanded and intensified in the sixteenth century. The northern Java coast was crowded with many rival ports (Raffles 1830,1:217), such as Demak and Cirebon. The Dutch merchant and explorer Willem Lodewycksz (d. 1604), who accompanied the first Dutch expedition to Java in 1596, also noticed that every major city in Java had its own king (Lodewycksz [1598] 1997:132), and that the most powerful of all was the king of Banten (Ikuta and Shibusawa 1981:152).

Against the backdrop of these conditions, political control in Island Southeast Asian polities often relied upon personal ties through exchanging prestige goods, establishing marriage alliances, performing ritualized feasting, and participating in religious and court ceremonies (Boomgaard 2007:61; Junker 1998, 1999, 2010 :283; Ricklefs 1981:15). Of particular importance to many elites in the region was the control of foreign prestige goods to expand and negotiate their material base for power (Junker 2004:233).

As a result of this unstable situation, the divine status and charismatic power of rulers in Island Southeast Asia were pivotal to politics (Geertz 1980; Tambiah 1976). An early sixteenth-century Portuguese resident in Melaka, Tomé Pires ([1515] $2005: 175)$, stated that "the lords of Java are revered like gods with great respect and deep reverence." Political gestures through feasting, dance, music, and entertainment often formed crucial elements of governing a state in many parts of the region. The American anthropologist Clifford Geertz (1980:102-104) argues in his seminal book on precolonial Balinese power processes, Negara: The Theater State in Nineteenth-century Bali, that the "performances" of the "theater state" of Bali are the state itself, centering on dramatizing power. Drawing from Negara, historian Johan Talens (1993:343-344) emphasizes the importance of Banten court rituals and the sultan's symbolic acts. The VOC records from 1691 depict the continuation of ostentatious court rituals for the coronation of Sultan Zain al-Abedin (r. 1690-1733). Multiple actors were present at the ceremony, including the VOC ambassador, punggawa (a group of Bantenese nobility), pungeran (prince), and commoners (Talens 1993:337).

\section{THE FOUNDING MYTH AND LEGITIMIZATION OF THE SULTAN'S POWER}

The Banten court chronicle Sejarah Banten, or "History of Banten," written by an unidentified Bantenese author in 1662-1663 (Djajadiningrat 1983:8), is an essential indigenous historical source that offers insight into the sultan's priorities and power relationships before the Dutch impacted his trade and diplomacy. As valuable a resource as this document is, it does not provide information about the sultan's daily activities in the palace, a gap that archaeology is uniquely well suited to fill.

Despite its title, Sejarah Banten should not be regarded as a history book in the strict modern Western sense. Detailed, precise information about historical events is lacking from the largely mythic-legendary text, which has as its main purposes legitimizing the royal lineage and preaching ethics based on Islamic beliefs (Boontharm 2003:3-4; Pudjiastuti 2000:4). It is important to note that the court document em- 
phasizes the significance of prestige derived from nonmaterial culture, generally not preserved in the archaeological record. As depicted in the court chronicle, the sultan obtained and sustained power through such strategies as marriage alliances, specialized knowledge, and personal glorification. These can be considered a classic example of "network" strategies as proposed by Blanton and colleagues (1996) and Feinman and colleagues (2000).

In Sejarah Banten, the sultan's connection to Islam was pivotal in legitimizing his power. Sejarah Banten goes so far as to proclaim that the sultan had a blood relationship with the Prophet Muhammad. The first ruler of Banten, Molana Hasanuddin, was a son of a venerated Muslim leader, Sunan Gunung Jati. Hasanuddin became a haji, a pilgrim to Mecca, and then established an Islamic kingdom in Banten. Hasanuddin and his two successors also used the title "Molana" to identify themselves as Islamic scholars and leaders. To further the status of Banten, its fourth ruler sought permission from the Grand Sharif of Mecca to use the title sultan.

Pre-Islamic symbols were also utilized to support the Sultan of Banten's power. For example, Sejarah Banten recounts how Hasanuddin acquired a powerful magic rock called a gilang from the Hindu Banten Girang (lit. "upstream Banten”), symbolizing his accession to the throne of Banten (Boontharm 2003:34-41; Pudjiastuti 2000: 188-189, 494).

Marriage alliances with well-established and powerful states in Java reinforced and enhanced the sultan's pedigree. Sejarah Banten records that Hasanuddin's father was the king of Pakungwati, a kingdom located in Cirebon, Java. His son (i.e., Hasanuddin) married Ratoo Raneh, the daughter of the Sultan of Demak in central Java (Mackenzie Private Collection 1816:29). Future Sultans of Banten thereby enjoyed the acclaimed position of having descended from two royal Javanese families from the kingdoms of Cirebon and Demak (Pudjiastuti 2000 : 187).

The court document considers the urban development of Banten the accomplishment of royalty. Sultan Molana is credited for being instrumental in building the city's major architecture and infrastructure, including Surosowan Palace, the Karangantu mosque, and canals (Pudjiastuti 2000:188-189) (Fig. 2). Sejarah Banten thus reveals that knowledge of Islam, blood relationships with venerated Muslim leaders, Mecca's acknowledgment of the sultan's right to rule Banten, the possession of a magical stone from the pre-Islamic period, and marriage alliances with other powerful states in Java were the pillars of legitimation that supported the sultan's hegemony and institutionalization of his power. Despite such claims to authority, the chronicle hints at numerous examples of the fluidity of the sultan's position and the complex and constant power negotiations he had to conduct with his officials and his allies (Boontharm 2003:3-4; Mackenzie Private Collection 1816:29; Pudjiastuti 2000:187-189).

\section{EUROPEAN INCURSION INTO BANTEN IN THE I68OS AND THEREAFTER}

The decade of the 1680s marked the beginning of indirect rule of Banten by Europeans, which lasted until the official end of the sultanate in 1813 (Ota 2006:145-146, 153). A civil war known as the Bantam War (1682-1684) broke out between factions who supported the popular former sultan Agung ("the Great") Tirtayasa (r. 1651-1683) and those who favored his son and successor, Sultan Haji (r. 1676?-1687) (Guillot et al. 1990:53). The war created a political vacuum in the sultanate. Fearful of losing the battle against his father, the young sultan Haji sought support and 


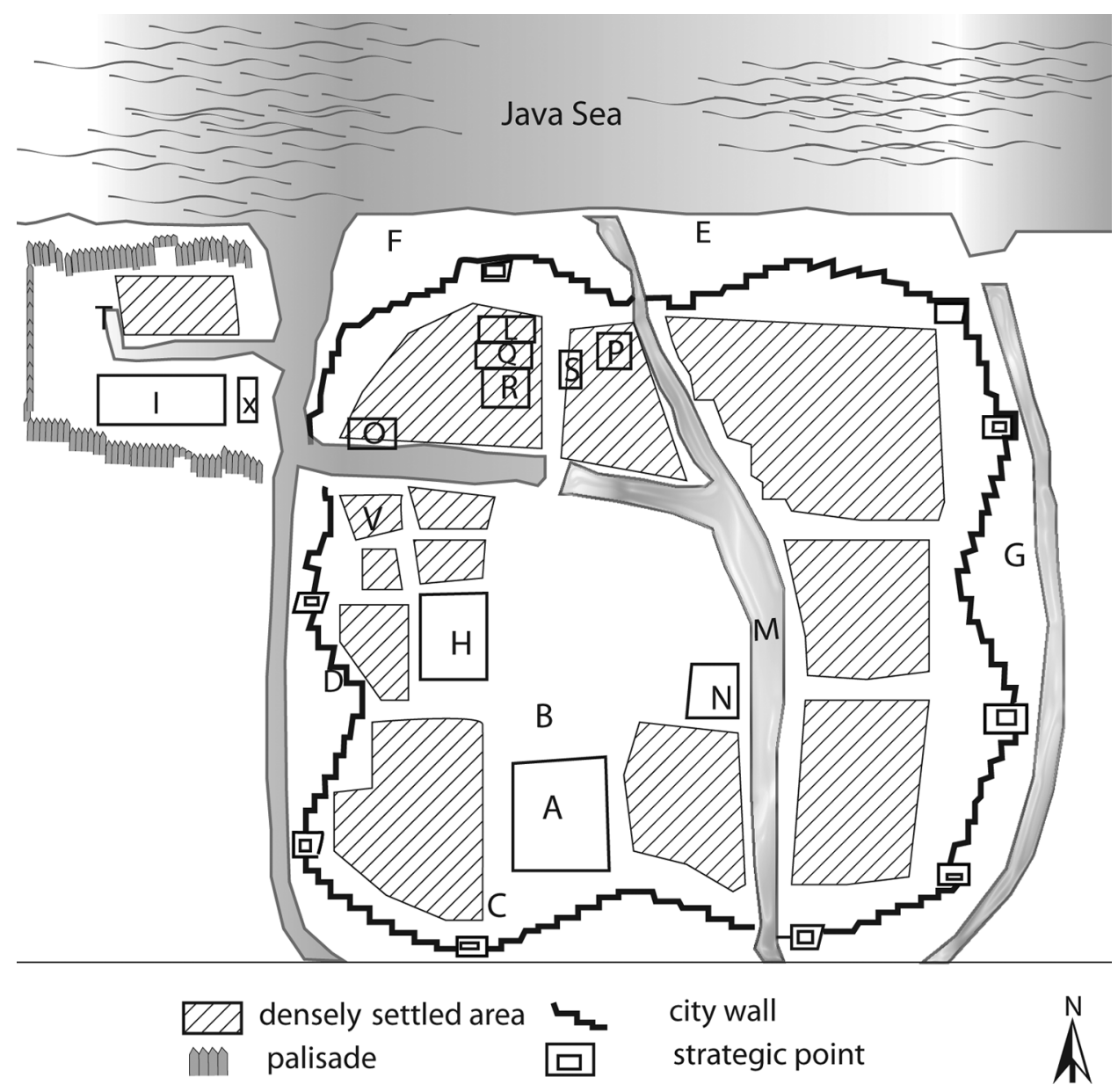

Fig. 2. Schematic map of Banten, redrawn after Plattegrond van Bantam, 1596 [Map of Banten, 1596] and rotated $180^{\circ}$ to position north upwards. The landmarks listed here are taken from the original map and use the original lettered labels (trans. J. Krzystek and K. Ueda). ${ }^{1}$

A: Royal palace; B: Paseban [courtyard, square in front of the palace for holding audience]; C: Land gate; D: Mountain gate; E: Sea gate; F: Barrier; G: Tower; H: Mesquita (Great Mosque); I: Chinese settlement; L: Residence of Banten's captain, Pangeran Gebang; M: River through the city; N: Residence of Sjahbandar; O: Residence of the admiral; P: Residence of Tjeti Maluku; Q: Residence of the governor's brother; R: Residence of Senopati; S: Residence of Panjang Jiwa; T: Chinese market; V: Residence of Andimon; X: Our factory [i.e., Dutch warehouse].

protection from the VOC. He took the unprecedented step of granting permission to the Dutch to build their headquarters, known as Fort Speelwijk, in Banten in the 1680s (Fig. 3). At the same time, Sultan Haji fortified his residence, Surosowan Palace, with a Dutch-engineered fortress that was manned by a VOC garrison. This fortress was later called Fort Diamond by the Europeans. The concessions given to the VOC did not end there. The sultan ceded his pepper trade monopoly to the VOC in exchange for military protection, and the sultanate became a vassal state of the Dutch East India Company in 1682 (Guillot et al. 1990:10; Miksic 1989: 6; Talens 1993:347). 


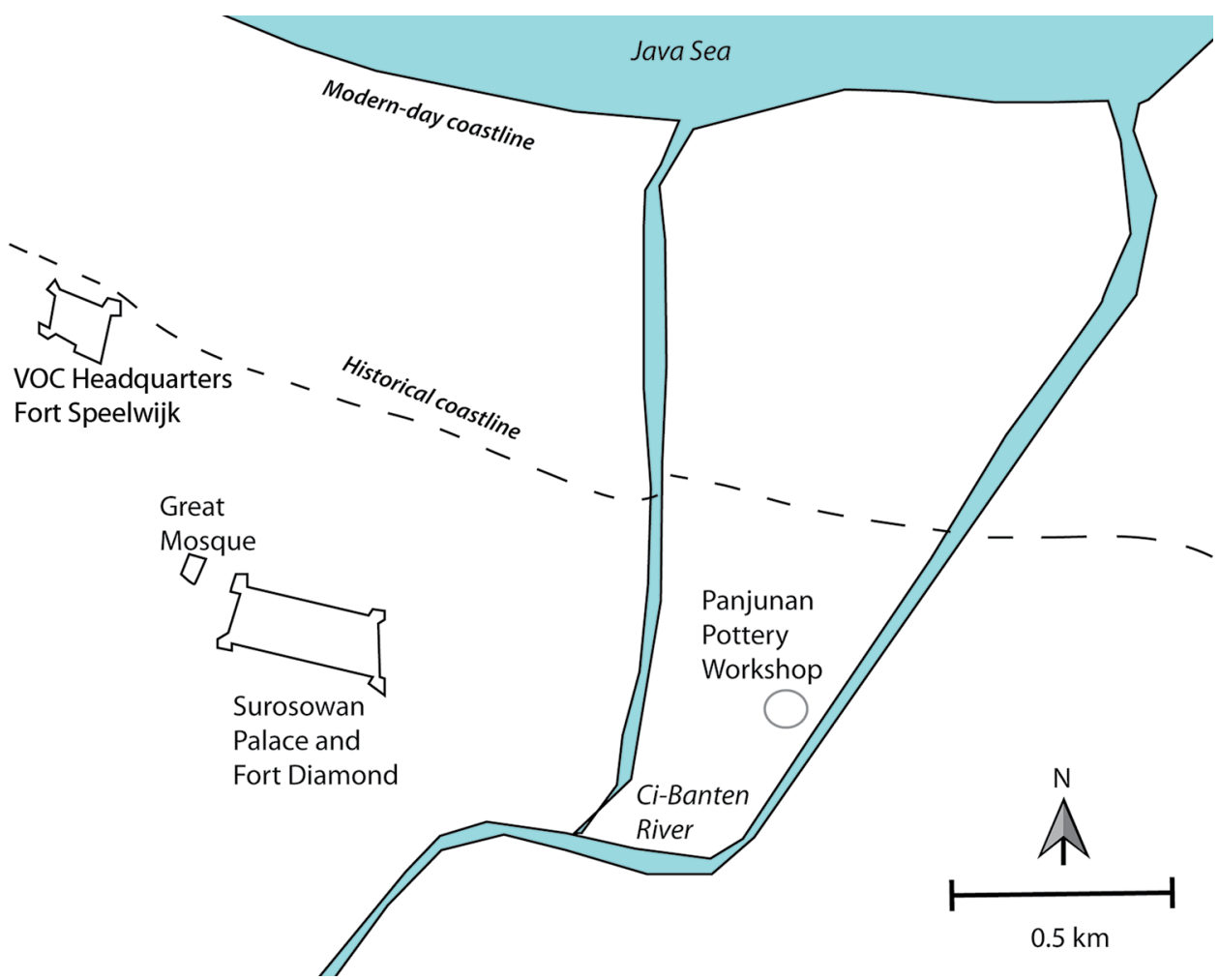

Fig. 3. Map of the Banten area, showing the key sites discussed in the text.

After the civil war, not only did Dutch architecture emerge along with their increasingly prominent military presence in Banten (Guillot et al. 1990:64-65), the spatial demarcation that had divided the foreigners from the Bantenese was fundamentally altered. Traditionally, no foreigners were allowed to stay inside the Banten city walls overnight, let alone build their own fortress within the city. The new military construction was a political message intended to demonstrate Dutch military power and its protection of the young sultan.

The rapid emergence of Dutch forts in Banten appears to corroborate an archaeological assessment that this change to the political landscape occurred within a relatively short period of time (Michrob 1982:5). However, a close reading of European historical documents, especially those written by lower-ranking VOC employees, reveals a somewhat different picture than the interpretation suggested by the monumental architecture. Although written from a foreign European perspective, some of these documentary sources seem to suggest that transformations in the sultan's power were quite complex and multifaceted. Various types of power may have coexisted side by side amongst those who wielded power in Banten. Sometimes they shared and mutually supported each other's claims to power, but often they contested them. Their manifestations of power may have been multidirectional and multilayered since they targeted different audiences, including those involved in diplomatic relations with 
other states, alliance building, and internal power negotiations amongst Bantenese nobility and the sultanate-VOC power balance.

Historical documents concerning royal pageantry in Banten suggest that the sultan continued to possess symbolic power, as well as perhaps the economic ability to support his status even after he was stripped of independent political power (Ota 2006). Christopher Fryke, a German physician who served the VOC during the 1682-1684 civil war, observed a sumptuous procession on a day of the sultan's departure to pay homage to the VOC governor. To Fryke, his majestic appearance carried an air of being "Lord of the Universe" (Fryke and Schweitzer 1700:163). This pageantry utterly surprised the VOC serviceman, who was well aware of the sultan's tenuous hold on political power. He concluded that the Dutch were willing to please the sultan "with this vain sh[o]w of Power and Greatness" (Fryke and Schweitzer 1700:163).

The somewhat conflicting historical and architectural records of Banten raise questions about the nature and time frame of the transformation in power amongst sultanates in Island Southeast Asia during the crucial period of early colonialism. We address these issues by evaluating the material culture of prestige goods recovered archaeologically from the Sultan of Banten's Surosowan Palace.

\section{EXCAVATIONS}

We excavated in Banten from 2009 to 2011 under the directorship of Naniek Harkantiningsih, who represented Indonesia's National Research Center of Archaeology. The primary objectives of the excavations included: 1) recover archaeological data from the indigenous sultan's Surosowan Palace, the VOC's Fort Diamond that surrounded the palace, and VOC headquarters at nearby Fort Speelwijk; 2) establish baseline archaeological data; and 3) study the types of material culture specific to the royal court as opposed to those available to the VOC garrisons.

A few notes of explanation are necessary about the spatial demarcation between Surosowan Palace and Fort Diamond, because this is not clear from either the architectural remains or the historical record. Archaeologists who had worked previously in Banten traditionally regarded the Dutch-engineered fortification that surrounded Surosowan Palace as part of the palace institution rather than as controlled by the VOC. We began our research by identifying the spatial boundary between the two institutions. The 1739 map Plan oder Grundriss des Königs und edl. Compagnies Fortresse in Bantam von den In[n]ländern Talm genannt; Kartenmaterial [Plan or layout of the King's and the Company's fortresses in Bantam called by Talm residents; maps] published by Johann Wolfgang Heydt (1744:109) provided significant insight into the different institutions (Fig. 4). According to Heydt's plan, the palace occupied the majority of the area inside the fortification wall, while the VOC facilities at Fort Diamond were largely at the four corner bastions and along the northern defensive wall. The protruding area along the northeastern defensive wall is unusual as a European fortress, and whether or not it belonged to Fort Diamond is unclear (Figs. 5, 6). Given the concentration of previously recovered European clay pipes in this area, we suspect that it was part of Fort Diamond or at least a location of intensive European activities (Ueda 2015:106-107).

We opened five trenches at Surosowan Palace and Fort Diamond in 2009 and 2010 and another five at Fort Speelwijk in 2011 (Fig. 7). Here we discuss the results of excavations at two units that generated data about palace residents during the 


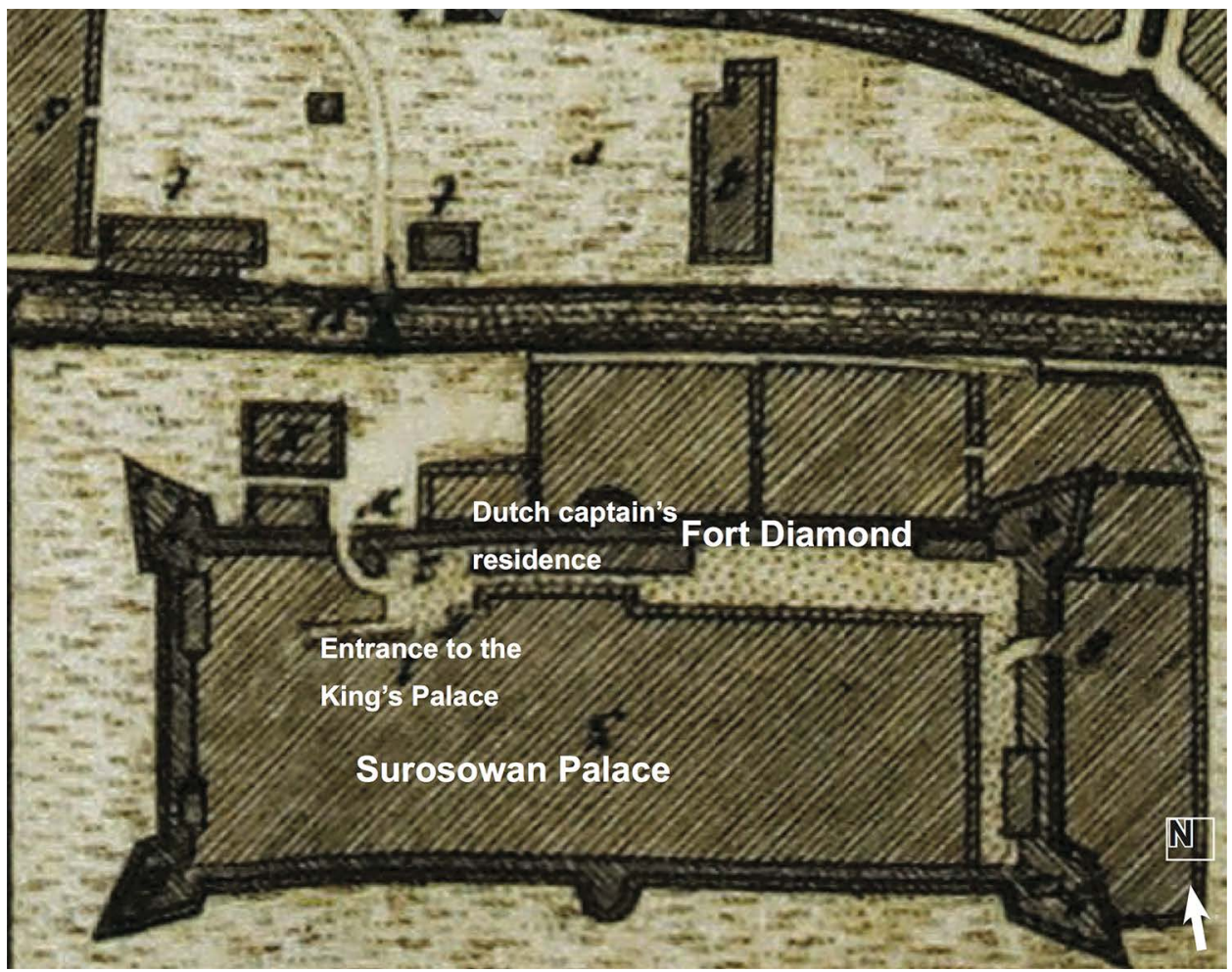

Fig. 4. Detail of the layout of Surosowan Palace and Fort Diamond as recorded in 1739. Rotated here to place north at the top; arrow and labels inserted by K. Ueda (adapted from Heydt 1744:109).

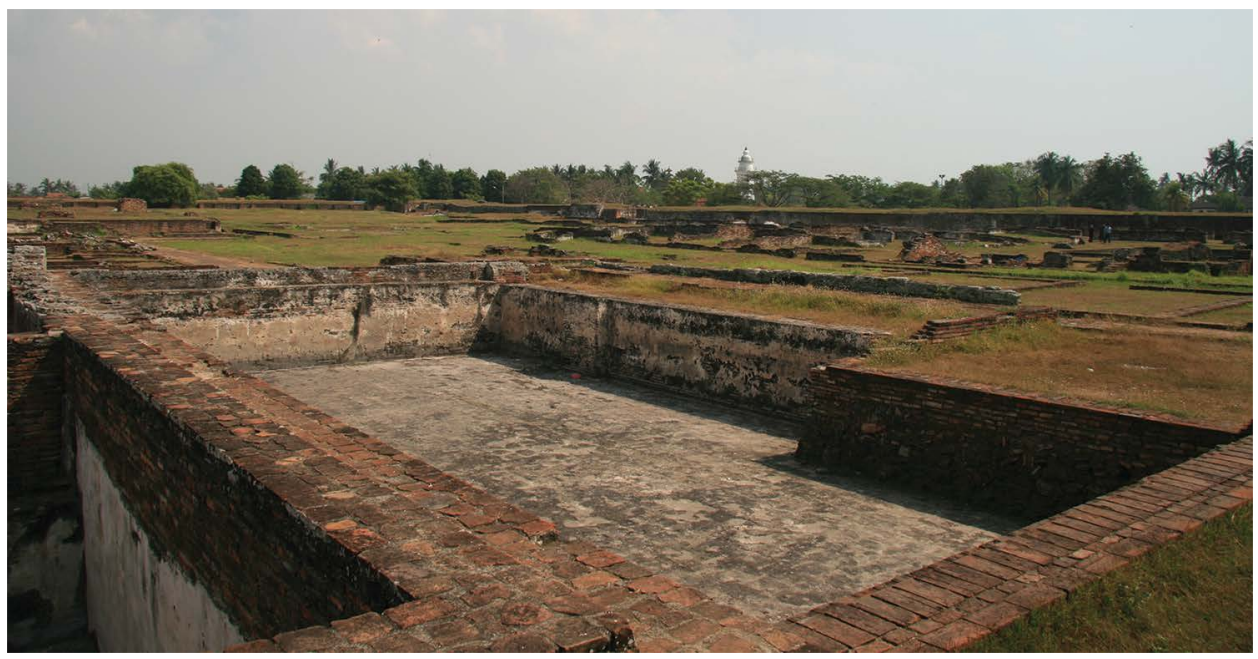

Fig. 5. The interior of Surosowan Palace looking northwest, with Fort Diamond fortification wall in the background. Photograph by C. Lim. 


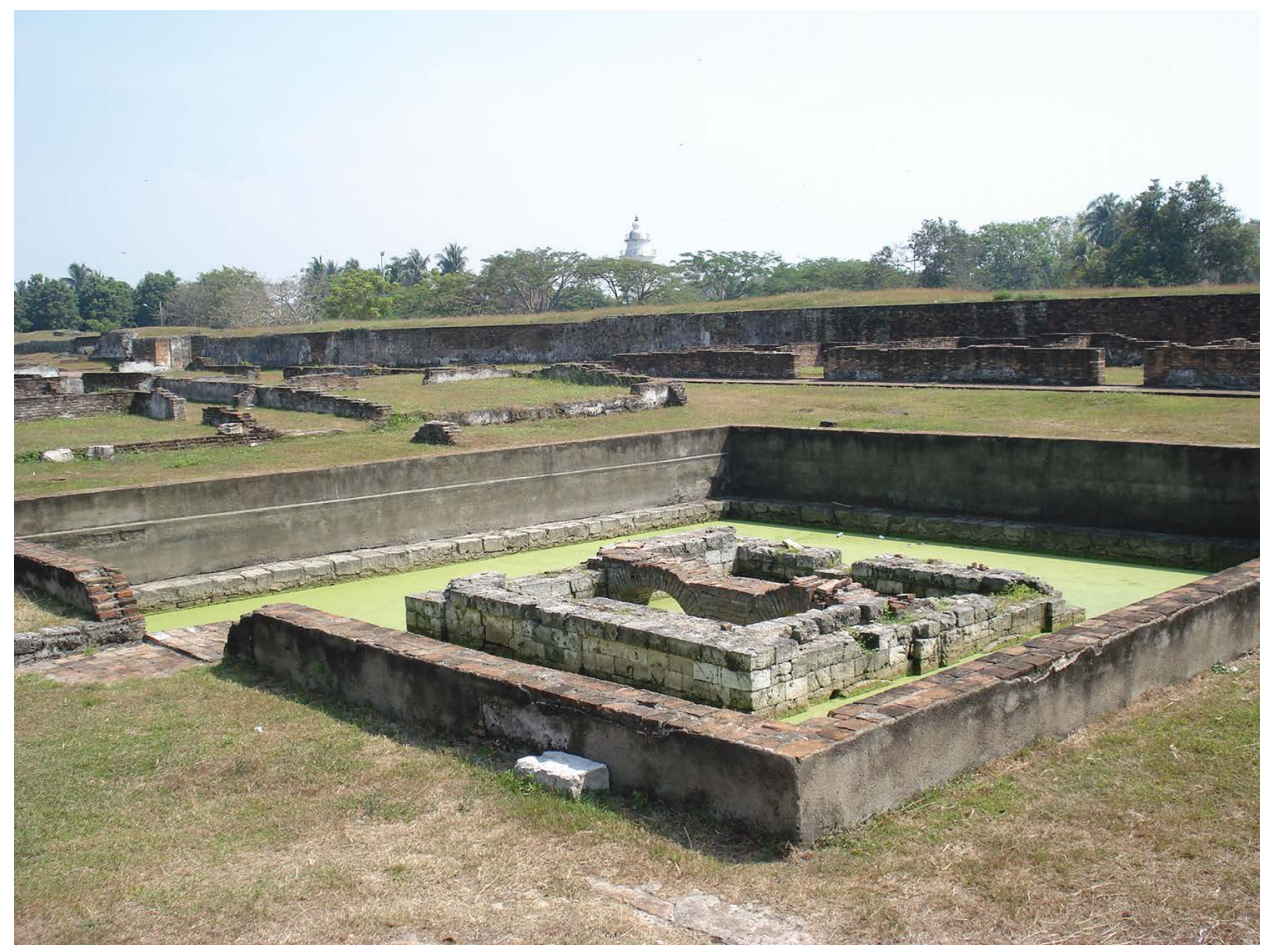

Fig. 6. A ritual pool inside Surosowan Palace, looking northwest. Photograph by K. Ueda.

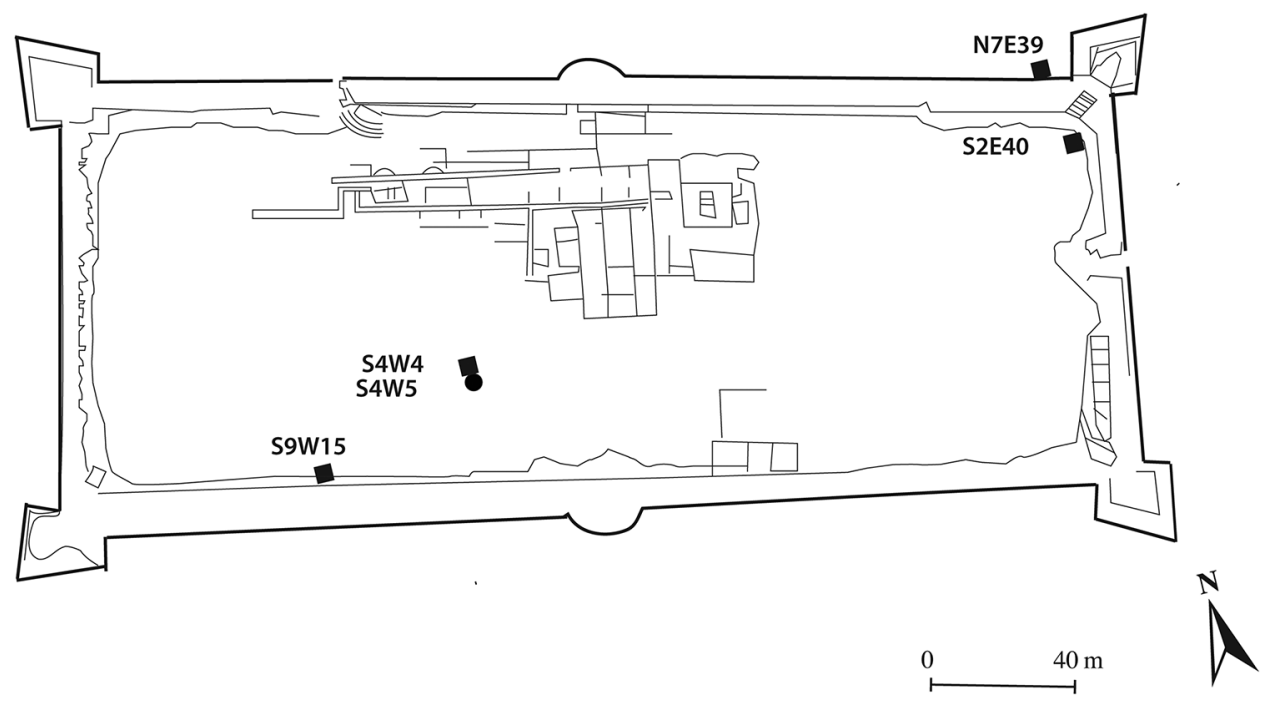

Fig. 7. Floor plan of Surosowan Palace and its surrounding fortification Fort Diamond, showing the units excavated in 2009 and 2010. 
Table i. Excavation Units Discussed in the TeXt

\begin{tabular}{|c|c|c|c|c|}
\hline LOCATION & $\begin{array}{l}\text { EXCAVATION } \\
\text { UNIT }\end{array}$ & EXCAVATION LEVELS & DATE & ASSEMBLAGE \\
\hline $\begin{array}{l}\text { Surosowan Palace } \\
\text { dumping area }\end{array}$ & S2E40 & $\begin{array}{l}\text { L1-L4 } \\
\text { L5-L7 } \\
\text { L8-L11 }\end{array}$ & $\begin{array}{l}\text { 19th century } \\
\text { 18th-early 19th century } \\
\text { 18th century }\end{array}$ & $\begin{array}{l}\text { Post-palace } \\
\text { Palace residence } \\
\text { Palace residence }\end{array}$ \\
\hline $\begin{array}{l}\text { Surosowan Palace } \\
\text { core area }\end{array}$ & S4W4 & $\begin{array}{l}\text { L2-L8 } \\
\text { L9-L17 }\end{array}$ & $\begin{array}{l}\text { 18th-early } 19 \text { th century } \\
17 \text { th-18th century }\end{array}$ & $\begin{array}{l}\text { Palace residence } \\
\text { Palace residence }\end{array}$ \\
\hline Fort Diamond & N7E39 & $\begin{array}{l}\text { L2-L5 } \\
\text { L6-L11 }\end{array}$ & $\begin{array}{l}\text { 18th-early } 19 \text { th century } \\
17 \text { th century? }\end{array}$ & $\begin{array}{l}\text { VOC } \\
\text { Pre-VOC }\end{array}$ \\
\hline
\end{tabular}

time Surosowan Palace was occupied and one unit at the surrounding Fort Diamond (Table 1). ${ }^{2}$ We dated the sites on the basis of excavated Chinese and Japanese porcelain and Dutch clay pipe bowls using the Gouda clay pipe bowl typology (Duco 1987).

\section{TYPES OF ARTIFACTS AND FAUNAL REMAINS THAT SIGNAL PRESTIGE}

Documentary and ethnographic accounts hint that a few types of food- and beveragerelated material culture may signal elite display of power and prestige in Banten: longnecked spouted ewers called kendi, water buffalo meat, and imported porcelain. Although they are not likely to be the only materials to demonstrate prestige, these types of artifacts and faunal remains are more statistically significant because we systematically can collect data to discern distributions, as opposed to, for example, one or two elephants that the sultan may have possessed. Additionally, they are less likely to be recycled and thus removed from the archaeological record than metal objects.

We focus on high-quality kendi drink-serving vessels, faunal remains from highstatus meats such as water buffalo, and imported porcelain because, together, these artifacts offer insight into the power negotiations and alliance-building activities that occurred during small-scale feasts and ceremonies. ${ }^{3}$ Unlike the sumptuous trappings of major events such as the sultan's procession to pay homage to the VOC governor, these objects were part of daily life. Although rarely mentioned in historical accounts, they signify the existence of wide trade networks and ritual activities and symbolize the power and prestige of the sultan.

\section{Kendi}

Long-necked, bulbous-bodied ewers called kendi are found in many sites in Island Southeast Asia, including at the twelfth- through fourteenth-century trading port at Kota Cina in northeastern Sumatra (Edwards McKinnon 1984:140-150; Miksic 1979:185-188, 2013:358), and at Trowulan, the capital of the Majapahit kingdom (1293-c. 1500) in east Java (Miksic 2013). Archaeologists often consider fine-paste kendi as evidence of the region's extensive trade activities because excavated kendi share similar stylistic and paste qualities (Edwards McKinnon 1984; Miksic 1979). 


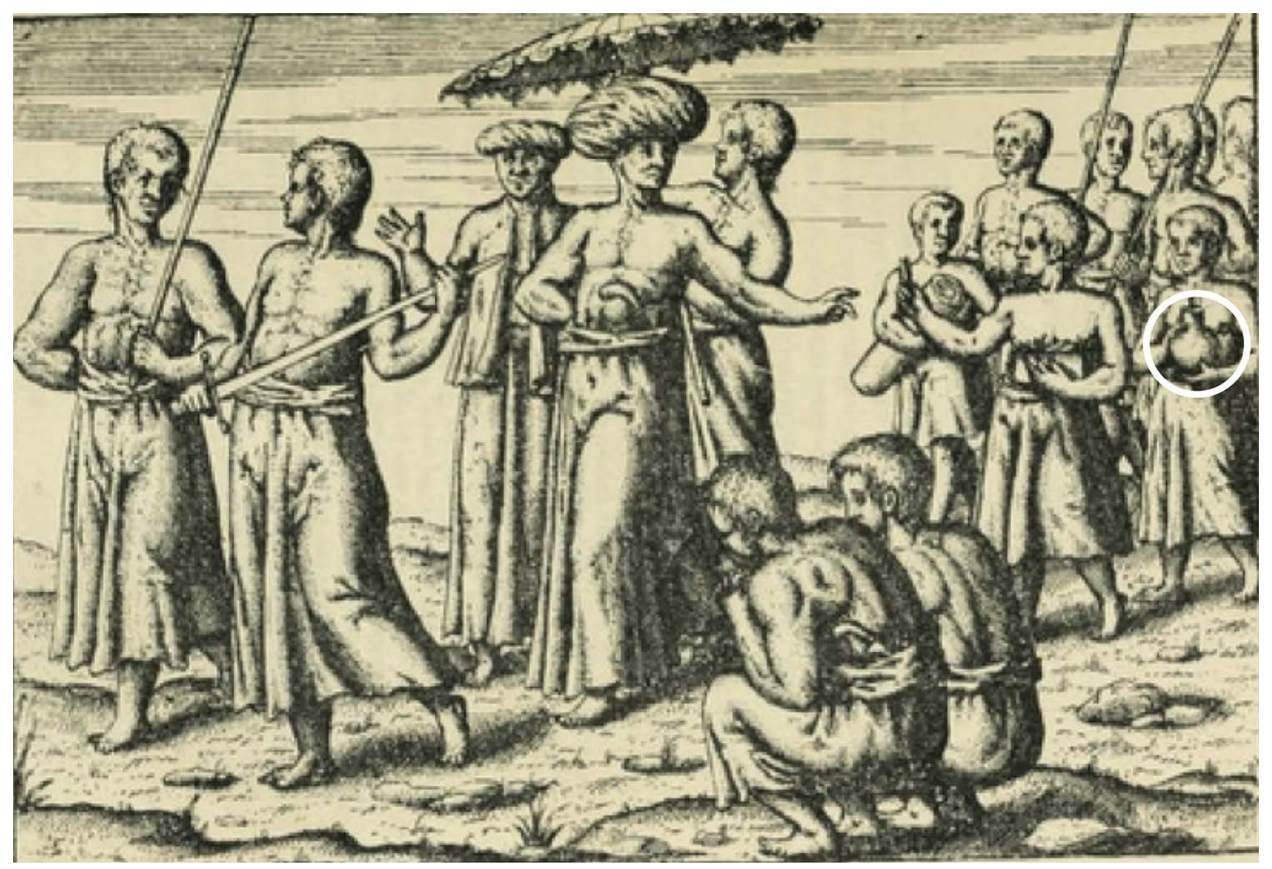

Fig. 8. Procession of a captain in Banten in 1596 showing a servant holding a bulbous-bodied, longnecked ewer, probably a kendi. From Rouffaer and Ijzerman 1915 :pl. 14; circle added by K. Ueda.

While they were used for a range of functions, from practical drinking vessels to ceremonial ware, they were most often used to hold water. The significance of water and kendi to the Bantenese is well documented (Sakai 1992a, 1992b, 2002b:225; Wibisono 1994:172-173). The Sejarah Banten, for instance, recounts that a minister named Ki Nayakusuma was responsible for carrying a kendi in the court procession (Pudjiastuti 2000:435). Lodewycksz ([1598] 1997) recorded a Bantenese captain's procession in which one of his servants reverently carried a kendi ewer (Rouffaer and Ijzerman 1915:119) (Fig. 8). Furthermore, a legend from Cirebon, where the father of Banten's first ruler originated, illuminates the prominent position of holy water and ewers or jugs. A founding myth describes a man named Anwar, the legendary ancestral figure for the entire population of Java, being given a magic jug that contains the water of everlasting life (Muhaimin 2006:61-62; Pudjiastuti 2000:188-189; Sulendraningrat 1978).

The ethnographic record supports historical texts that suggest kendi were used for ceremonial purposes in Java. In a traditional Javanese wedding, for instance, a piece of decorative textile is draped over a pair of kendi. In a ritual borrowed from the Indian tradition, the Javanese bride washes her groom's feet with water poured from a kendi as a symbolic gesture of nuptial harmony (Adhyatman 1990:32; Eng-Lee 1984:14). Thus, both historical and ethnographic records indicate that some kendi, perhaps particularly high-quality vessels, were associated with the sacred qualities of water and were used prominently in ceremonial settings to exhibit elite status and power in Bantenese society. 


\section{Water Buffalo Meat}

While elites might or might not have drunk from high-quality kendi, their status would certainly have been conveyed by the meat they consumed. Among various types of meat, large mammals, especially water buffalo, carry higher prestige and economic value in Indonesia. The ethnographic record we collected daily at the traditional open-air market in Banten during the three field seasons between 2009 and 2011 suggests that the basic local diet consists of chicken, small fish, rice, and tempeh (fermented soybean patties), but not the meat of large mammals (Ueda 2015:273). The non-quotidian nature of animal meat is underscored in the Sejarah Banten, which depicts numerous banquets serving water buffalo meat. One such occasion was to entertain the guests of Sultan Agung (r. 1651-1683), highlighting this animal's cultural significance and the prestige it accrued to the Bantenese royal family (Pudjiastuti 2000 : 491). The court document also proudly states that the Sultan's soldiers once raided the Dutch military camp, where they captured cows and water buffalo in addition to weapons, flags, trumpets, parasols, and people from Kalasi, Wandan, and Malewar who were living in the Dutch camp (Pudjiastuti 2000:531). ${ }^{4}$

In contrast to water buffalo, pork most likely occupied the low end of the meat preference scale at Banten. Because the Sultanate of Banten was regarded as "selfconsciously Muslim" (van Bruinessen 1995:165), and the sultan used the Islamic religion to help define his kingdom and power, the Bantenese would be expected to have renounced pork consumption. Furthermore, ethnographic evidence suggests that meat - specifically pork - is considered an ethnic marker for the Dutch. Hildred Geertz (1961:86-87), an American anthropologist who specialized in Javanese culture in the mid-twentieth century, observed that people living in Java generally favored rice and fish and that meat consumption was something that divided the Javanese from the Dutch.

\section{Imported Porcelain}

Imported porcelain, dominated by Chinese production, is traditionally considered one of the major foreign prestige goods procured and manipulated through the maritime trade networks in early modern Island Southeast Asia (Junker 1999: 4; 2001, 2010). It was actively incorporated into elite rituals and ancestor veneration at Banten-related sites. For instance, in the court of Cirebon, which was connected with the founder of the Sultanate of Banten, people used antique imported porcelain dishes to serve rice at fertility rituals (Adhyatman 1990:45). A nearby mausoleum belonging to Sunan Gunung Jati, the venerated father of the first sovereign of Banten, is beautifully adorned with Chinese vases (Adhyatman 1981:149-151).

The values and roles of Chinese porcelain in different consumption societies are dynamic and complex (Ohashi 2004; Sakai 2002a; Vainker 1991). Chinese porcelain deserves more complex interpretations than the usual simplistic statements equating it with high economic and status values. Instead of grouping all Chinese porcelain together, making distinctions by place of origin allows historical archaeologists to answer a range of questions concerning trade and social class. For example, it is important to distinguish between ceramics produced at Jingdezhen in Jiangxi Province from those produced in the Fujian and Guangdong Provinces of southern China. For 
this reason, we categorize different Chinese porcelains by place of manufacture. We also distinguish porcelains by period of production. Although this approach is far from complete or comprehensive, it is a good starting point for addressing the complexity involved in recognizing the prestige value of Chinese porcelain.

Jingdezhen porcelain is generally considered more refined and thus more expensive. Jingdezhen kilns pioneered the technique of painting in a cobalt blue underglaze; large-scale production of blue-and-white porcelain was in full swing by the early sixteenth century (Kerr and Wood 2004:449; Medley 1976:171; Ohashi $2004: 56-58)$. By the turn of the seventeenth century, Jingdezhen potters were cultivating the high-end markets of Europe, where they sold their products at a premium (Dias et al. 2013; Harrisson 1979). Their porcelain was the initial inspiration for Delftware potters to begin imitating Chinese porcelain in the Netherlands (Noël Hume $1970: 258$ ). Europeans started mass producing hard- and soft-paste porcelains (the latter called "refined earthenware" by American historical archaeologists) in the eighteenth century (Vainker 1991:157-159).

Blue-and-white porcelain of a lower quality than those from Jingdezhen began to be produced at kilns located along the southern coast of Fujian Province in the sixteenth century (Ma et al. 2012; Ohashi 2004:58-59). Zhangzhou, the site of the most important kiln in Fujian, became a major ceramic production center for the export market in the sixteenth to mid-seventeenth century (Fujian Provincial Museum 1997:112-121; Ohashi 2004:87). Zhangzhou porcelain, known as Swatow ware among Western collectors, was well received in Southeast Asia and Japan despite its generally being of poorer quality and made from a relatively coarser paste than Jingdezhen porcelain (Harrisson 1979; Vainker 1991:145-146). Zhangzhou porcelain production declined in the late seventeenth century as other kilns farther south in Fujian became more active porcelain exporters (Ohashi 2004:87).

We use the term "Fujian/Guangdong" as a combined place of manufacture because it is difficult to visually distinguish ceramics produced in these two provinces. Production occurred primarily in small-scale private kilns in both areas, making it difficult to grasp the broader landscape of production (Kerr and Wood 2004:241; Sakai 2002a). Furthermore, the production of Zhangzhou ware might have originated in Fujian but later spread to northern Guangdong (Morimura 1995:364). In any case, by the eighteenth century, Fujian/Guangdong ware had become quite inexpensive in Asia. This "coarse provincial" ware from southern coastal China satisfied many of the basic needs of VOC posts in Island Southeast Asia (Lucas $2004: 36) .{ }^{5}$ Along with finer Jingdezhen ware, it comprises a substantial part of ceramic assemblages found at VOC sites throughout the Indian Ocean region.

China's political whims impacted production centers in Jingdezhen and Fujian/ Guangdong and affected the availability and economic value of Chinese porcelain from the Ming (1368-1644) through the Qing (1644-1912) periods (Vainker 1991: 136, 176). Most relevant to our study are the civil wars between the Ming and Qing armies at the beginning of the Qing period. These wars disrupted Chinese ceramic production, especially in areas of Jingdezhen from 1644 to 1684 (Fang 2002:108-109; Ohashi 2004:83, 141). Jingdezhen factories were particularly devastated during a rebellion led by General Wu Sangui 吳三桂 from 1673 to 1680 (Medley 1976:216). In addition to the destruction of porcelain factories during wartime, the export of Jingdezhen porcelain was curtailed when the Chinese imperial government banned maritime activities, including private overseas trade, be- 
tween 1656 and 1685 (Fang 2002:109). The ban was instituted to obstruct maritime trade that was financing an antigovernment force (Hong Kong Urban Council et al. 1996:126).

Fujian/Guangdong potters were generally more nimble exporters than those in Jingdezhen. Their proximity to ports, smaller-scale operations, and extensive overseas networks enabled them to continue trading porcelain despite the ban. Ohashi Koji (2004:112), a specialist in exported Asian porcelain, surmises that these advantages allowed Fujian/Guangdong potters to smuggle more porcelain out of China than Jingdezhen producers. As a result, political conditions affected the production and export capabilities in Jingdezhen more than in Fujian/Guangdong. This significantly influenced the manufacturing sources of Chinese porcelain available to consumers in Banten (Ohashi and Sakai 1999; Sakai 2002b).

The role that Chinese porcelain played in Bantenese society also appears to have changed over time. Ohashi Koji and Sakai Takashi (a Japanese archaeologist working in Indonesia) conducted a stylistic and vessel type analysis on approximately 300,000 non-local ceramic sherds (minimum number of vessels [MNV] 24,990) that had previously been excavated from Banten in the 1970s and 1980s (Ohashi and Sakai 1999). Synthesizing the results of this research, Sakai (2002a:101-102) notes that the types of Chinese porcelain in Banten changed around the mid-seventeenth century, shifting from prestige items primarily for royal residents to daily ware for the mass market. By the beginning of the eighteenth century, a large amount of porcelain had flooded the Banten market and ended up in the hands of ordinary, non-elite consumers. Sakai concludes that eighteenth-century Chinese porcelain in Banten primarily includes small bowls from Fujian/Guangdong and plates from Jingdezhen, rather than the large plates and ornamental items typically found in Banten during the sixteenth and seventeenth centuries. This body of research highlights the importance of understanding the shift in economic value of Chinese porcelain in Banten from exclusively high-end to ordinary mass market over time instead of assigning uniformly high values to all Chinese porcelains irrespective of place or time of manufacture. We took a similar approach in our analysis of excavated Chinese porcelain.

\section{EXCAVATION RESULTS}

The results of excavations support our initial assessment regarding the spatial demarcation between Surosowan Palace and Fort Diamond. This spatial demarcation was corroborated by a high concentration of European clay pipes at the northeast corner, immediately outside Surosowan Palace's defensive wall. Fort Diamond (excavation unit N7E39) yielded 13 times more clay pipe stems $(n=476)$ and 37 times more clay pipe bowls $(n=148)$ than found in the contemporaneous layers of the dumping area (S2E40) within the Surosowan Palace walls. No clay pipes were excavated from the Surosowan Palace core area (S4W4). Consequently, we dated the palace core area solely on the basis of Asian porcelain, although that made it difficult to establish a detailed chronology. Nonetheless, we suspect that seventeenth- to eighteenth-century layers largely reflect court activities after the sultanate became the VOC's vassal state in 1682, since the palace underwent major renovations during the time Fort Diamond was constructed.

Assemblages recovered from the two units within the palace, the dumping area and core area, are slightly different. Assemblages from the dumping area reflect refuse 
associated with all palace residents and may even include some mixing with construction debris from the VOC activity areas. The core area unit generated higher quality Ming Chinese porcelain, limited large animal bones (from parts of animals usually butchered first), and an overall scattered distribution of artifacts. These archaeological patterns, combined with the unit's location in a central area of the palace, suggest that it mirrors consumption activities of palace residents such as the sultan, his family, and his immediate servants.

\section{Kendi}

The recovered earthenware can be categorized into coarse-paste utilitarian ware and finer-paste ware, the latter being identified primarily as parts of kendi. Hard-bodied, wheel-turned, thin-walled, and commonly burnished sherds found in Banten are typical of kendi. Their finer-grained clay and finishing features distinguish them from utilitarian ware associated with cooking and storage functions.

The results of petrographic analysis demonstrate that the utilitarian coarse paste ware was made with locally available sandy coastal clay in Banten. This analysis included earthenware excavated at Surosowan Palace and collected at the contemporaneous Panjunan pottery workshop less than a kilometer east of the palace, as well as experimental samples made with clays collected around Banten. The identified clay type consists primarily of large subangular quartz and plagioclase, without much discernable production elaboration such as sieving or burnishing. The overall quality is poor with many large, elongated voids (empty spaces in the clay), probably created at the time of firing.

Finer-paste ware can be divided into locally produced kendi and imports. The former were made with locally available clay that was sieved and then burnished, resulting in a medium-quality paste that retains the overall coarseness of the local clay. The imported ware was produced using a finer clay consisting of small, subrounded quartz and small quantities of mica. This clay is not obtainable in the immediate Banten area to the knowledge of the authors. Many samples of the fine-paste ware were tempered with markedly finer volcanic ash than that occasionally observed in Banten ceramics. Although a determination of the kiln locations that produced these excavated finepaste kendi would require further study, an abundance of similar fine-paste kendi excavated from consumption and kiln sites in east Java suggest that kendi were produced in this region (Guo 2011; Ueda 2011, 2013, 2015; Ueda et al. 2012) (Fig. 9).

The distribution of kendi is more concentrated at Surosowan Palace (particularly the core area) than at Fort Diamond (Table 2). The core area yielded more fine-paste kendi than did the dumping area. Both fine- and medium-paste sherds decline at the core area from the seventeenth to early nineteenth centuries.

The pattern of distribution of kendi is quite different from that of various forms of utilitarian coarse earthenware. The forms of coarse earthenware are primarily represented by traditional Bantenese open-mouth cooking pots (periuk), rice steamers (dandang), straight- or slightly curved-bodied bowls with everted rims (pasu), horseshoe-shaped cooking stoves (tungku), and cylindrical cooking stoves (anglo). ${ }^{6}$ These types of ceramics are considered to be part of traditional cooking and storage ware in Banten, so these findings highlight the continued importance of local production for daily ware and utilitarian vessel forms (Ueda 2015:164-165, 252). While a detailed analysis of coarse earthenware is outside the scope of the present work, it is 

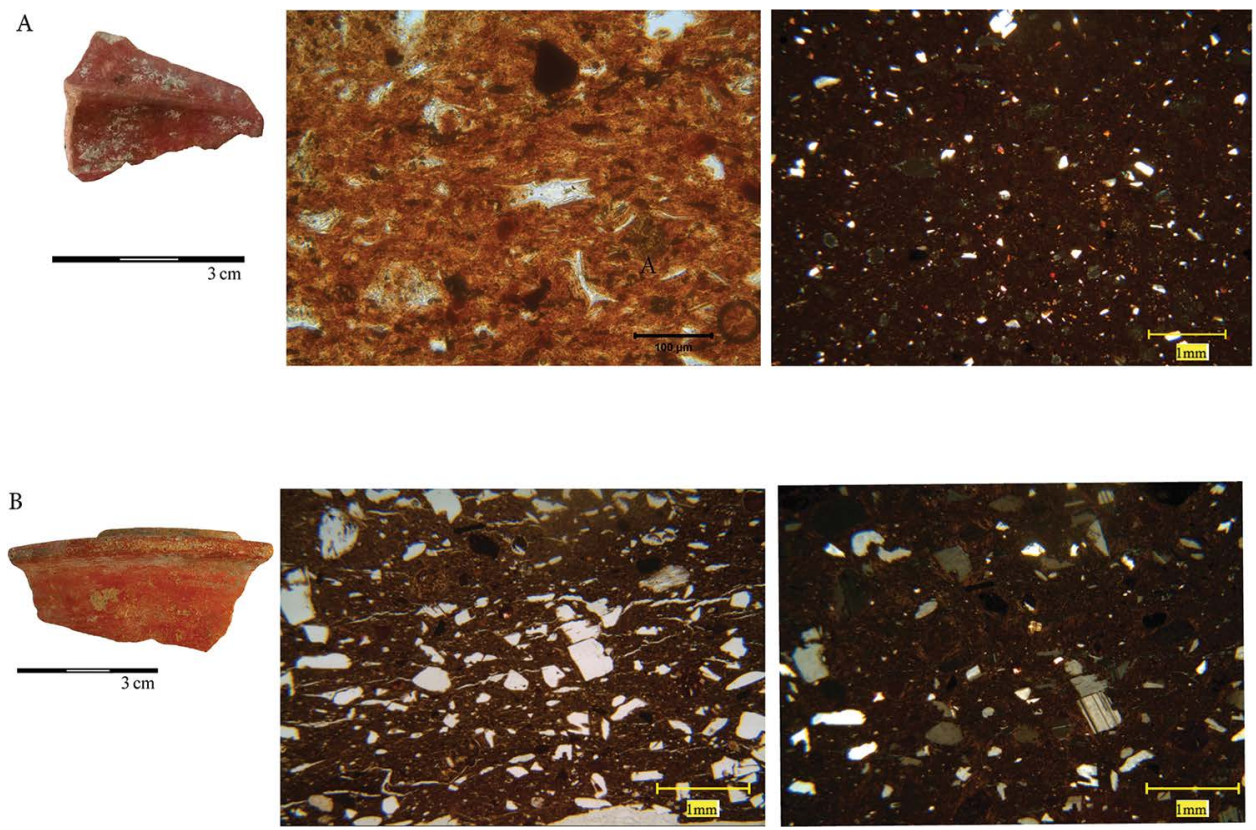

Fig. 9. A: A fine-paste kendi fragment made with non-local clay excavated from the Surosowan Palace core area (S4W4 L12) and examples of petrographic images under (center) plain polarized light, PPL $(200 \mathrm{x})$ and (right) cross-polarized light, XPL (20x). The PPL images are shown at 10x higher magnification to highlight the lens- and Y-shaped volcanic ash; B: a medium-paste kendi fragment made with local clay collected from Panjunan pottery workshop and petrographic examples under (center) PPL (25x) and (right) XPL (25x). Photographs by K. Ueda.

worth noting that their diachronic and spatial distribution patterns are complex. Periuk cooking pots increase over time at the Surosowan Palace dumping area, but slightly decrease at the core area. Dandang rice steamers, considered quintessentially Southeast Asian cooking vessels, are distributed only at the Surosowan Palace core area and increase over time. Tutup (lids), the most numerous ceramic form at Fort Diamond, decrease over time at the Surosowan Palace dumping area and only marginally increase at the core area, while pasu bowls, the second most numerous form at Fort Diamond, increase at both palace locations.

Notably, we did not excavate any European or European-style earthenware cooking vessels at either Surosowan Palace or Fort Diamond. Although some cooking vessels used in Banten are likely to have been made of metal, the excavated earthenware suggests a continuity of local culinary traditions at Surosowan Palace, without much European influence, from the seventeenth through the early nineteenth century.

\section{Imported Porcelain}

The porcelain excavated at Surosowan Palace and Fort Diamond primarily consists of plates and small bowls. In both seventeenth- and eighteenth-century layers of the core and dumping areas, the percentage of small bowls is higher than that of plates. Plates slightly outnumber small bowls in the core area's later deposits, but not to the extent observed at Fort Diamond (Fig. 10). 


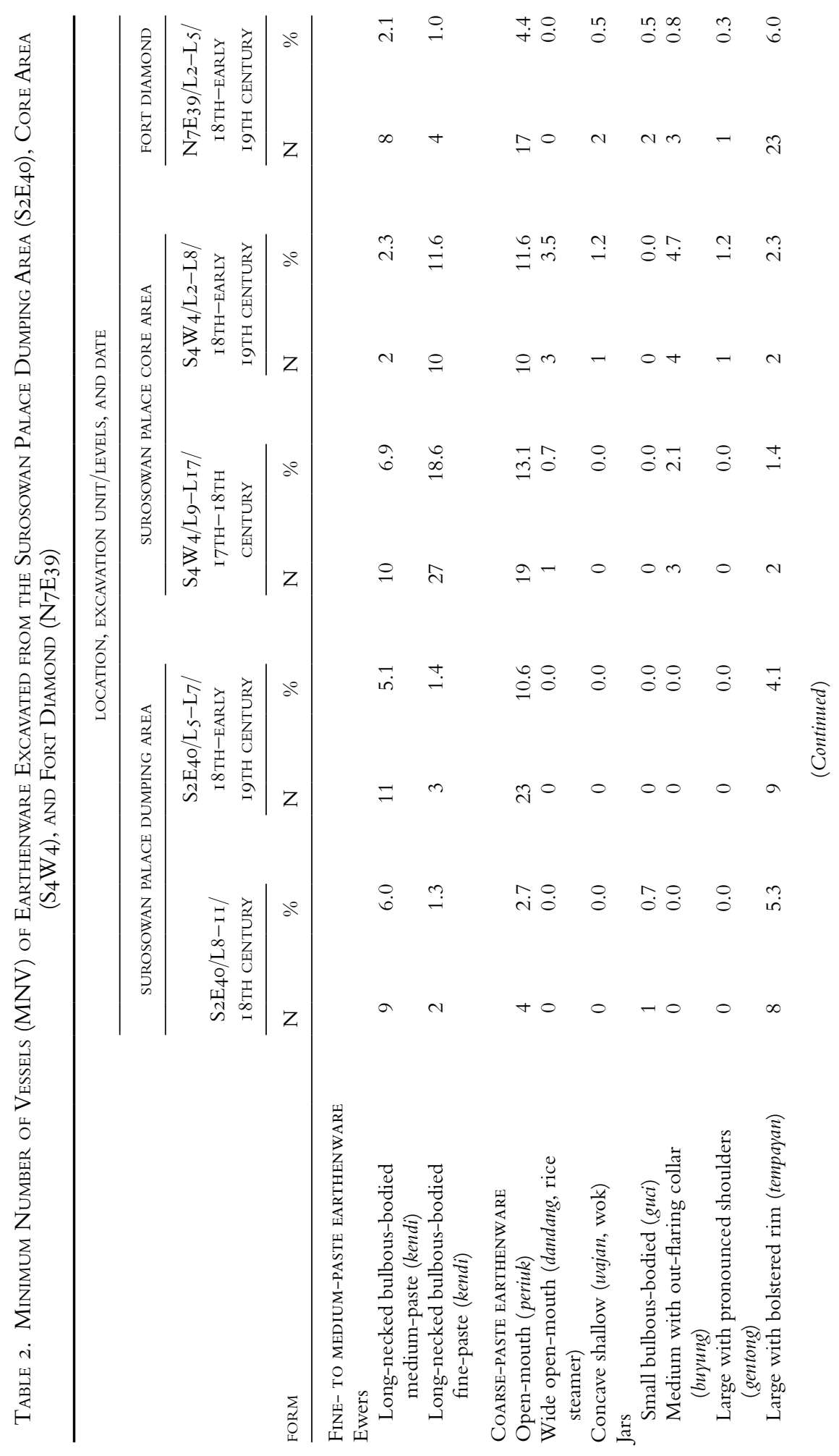




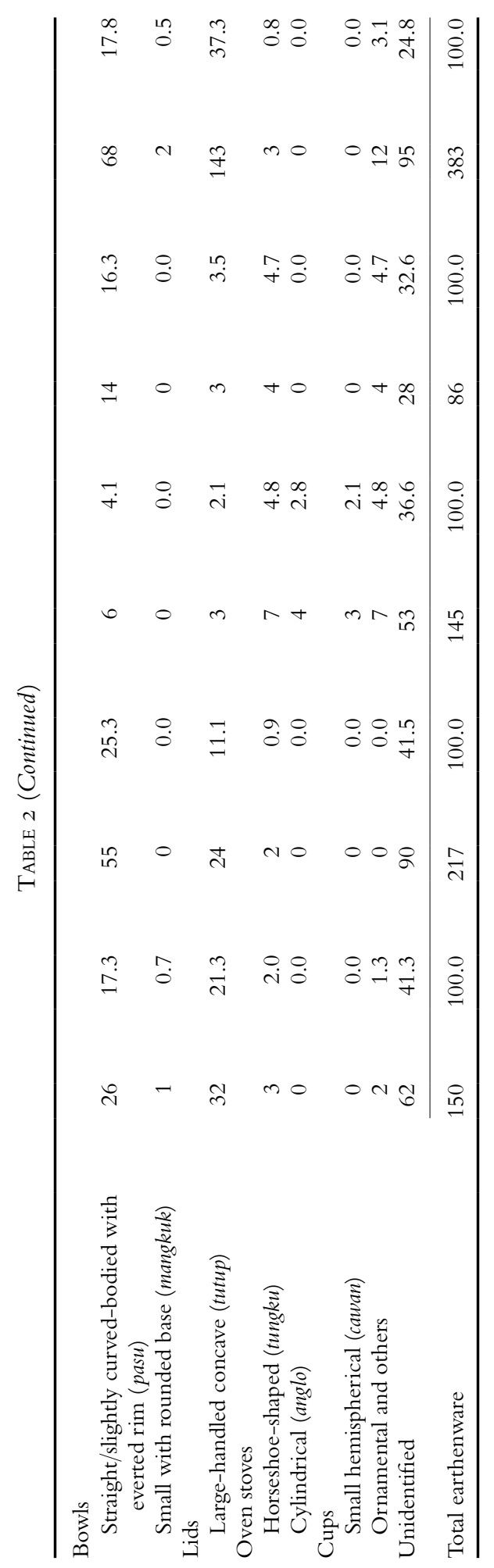




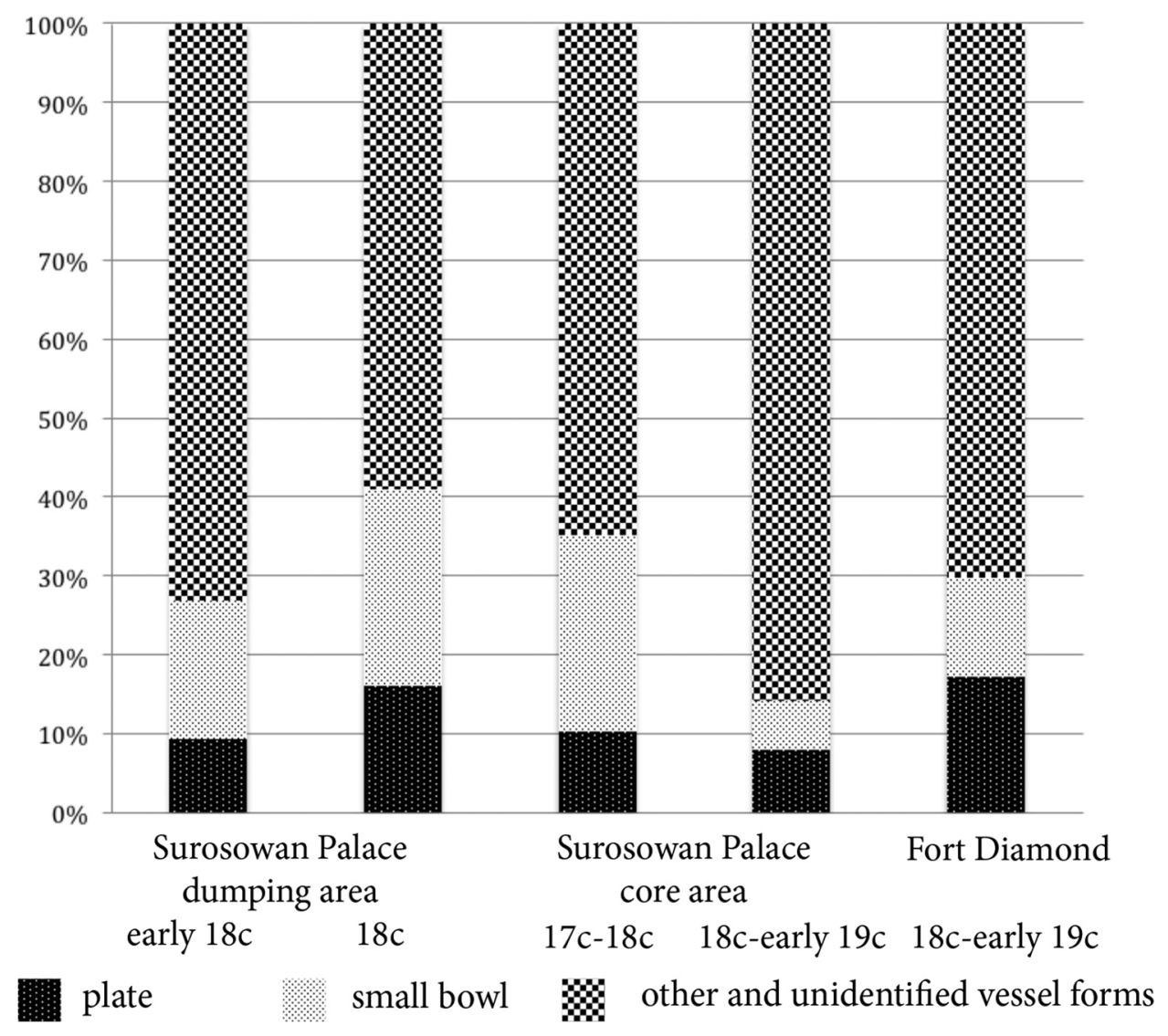

Fig. 10. Percentage MNV of porcelain excavated from the Surosowan Palace dumping area (S2E40), core area (S4W4), and Fort Diamond (N7E39) by vessel form $(\mathrm{n}=1746)$.

No Delftware or other European food-serving vessels were excavated. Chinese porcelain, represented by both Jingdezhen and Fujian/Guangdong ware, dominates the porcelain assemblages excavated at Surosowan Palace regardless of location or time period, suggesting China's enduring role as a provider of ceramic vessels (among other products) to the sultanate (Fig. 11). Although the percentage is lower than at Surosowan Palace, Chinese products also dominate the porcelain assemblage at Fort Diamond. This supports the contention that both Bantenese and Dutch had access to Chinese trade networks and both preferred porcelain made in China over those from other places of manufacture.

We found a higher percentage of Jingdezhen ware at Surosowan Palace than at Fort Diamond, although it decreases over time at the two palace sites. This decline is countered by an increase in Fujian/Guangdong porcelain. Jingdezhen and Fujian/ Guangdong ware do not demonstrate a consistently differentiated distribution between the two palace sites, although Jingdezhen dominates the Surosowan Palace dumping area while Fujian/Guangdong porcelain outnumber those from Jingdezhen at the core area. The concentration of Fujian/Guangdong porcelain dating to 


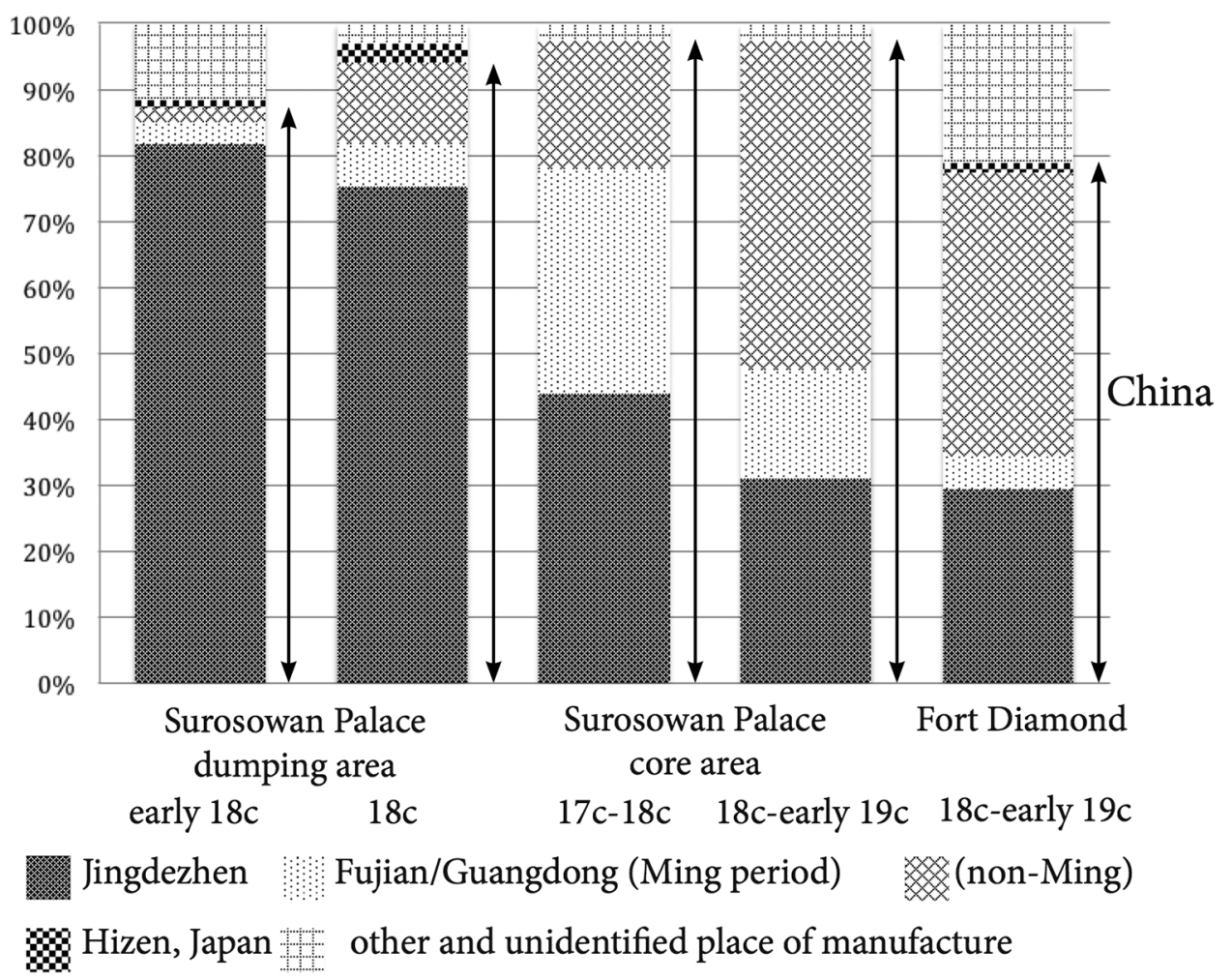

Fig. 11. Percentage MNV of porcelain excavated from the Surosowan Palace dumping area (S2E40), core area (S4W4), and Fort Diamond (N7E39) by place of manufacture $(n=1746)$. The arrows represent Chinese production.

the Ming period, which may be heirlooms, could explain the high ratio of Fujian/ Guangdong ware at the core area in the seventeenth to eighteenth century. However, the porcelain assemblage at the core area becomes dominated by Fujian/Guangdong porcelain from the Qing-Ming transition (1620-1683) and Qing period by the eighteenth to early nineteenth century.

\section{Faunal Remains}

A significant number of water buffalo and cow bones were recovered from the Surosowan Palace dumping area, but not from the core area and Fort Diamond (Fig. 12). The two taxa, water buffalo and cow, combined represent 23.6 percent of the total Number of Identified Specimens (NISP) in the early eighteenth-century assemblage, but decline to 13.6 percent in later deposits. Combined with unidentified large mammal remains, total large mammal bones represent 68.3 percent in the early eighteenth century and decrease to 37.0 percent later in the century. This decline is essentially countered by an increase in the number of bird bones, primarily fowl.

The Surosowan Palace core area generally yielded smaller bone fragments, and the pattern of finds suggests that these bones were discarded ad hoc after the consumption of the meat, not as a result of systematic trash disposal as we found in the dumping 


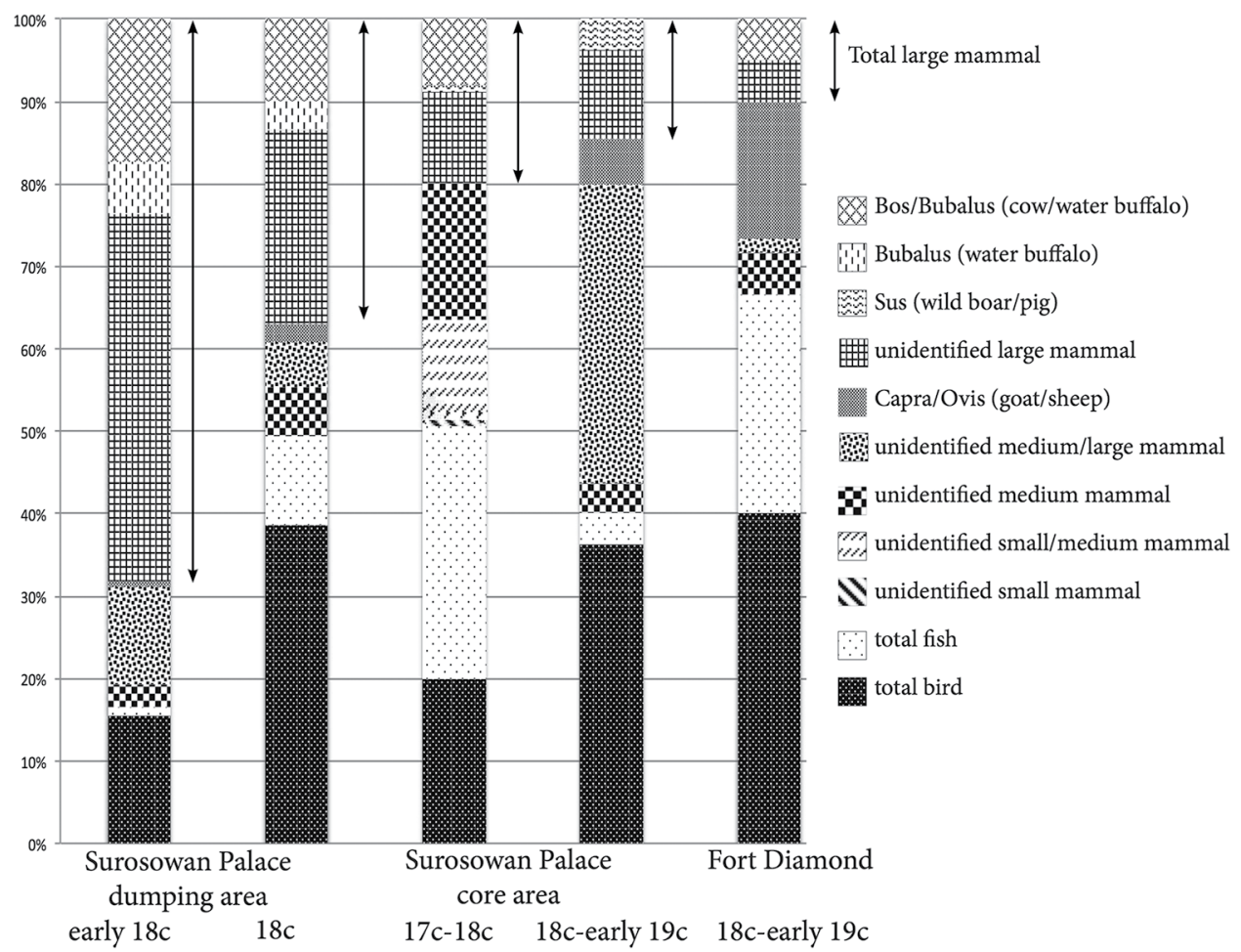

Fig. 12. NISP of faunal bone remains from the Surosowan Palace dumping area (S2E40), core area (S4E4), and Fort Diamond (N7E39). The arrows represent the large mammal species $(\mathrm{n}=948)$.

area. Two fragments of pig or wild boar lower jaws with teeth still attached were excavated at the Surosowan Palace core area. As these finds were not associated with the remains from other, more commonly consumed parts of the animal, we cannot conclude with certainty that these fragments indicate the consumption of pork by court residents. The relative abundance of large mammal remains, particularly those of water buffalo, decreases from the seventeenth- to eighteenth-century assemblage $(19.8 \%)$ to that from the eighteenth to early nineteenth century $(14.5 \%)$, while the number of bird bones increases.

The faunal assemblage from Fort Diamond reveals a different distribution of animals consumed compared with Surosowan Palace. Fish and bird bones comprise 66.7 percent of this assemblage while red meat consumption appears to have been more limited, with animals identified as sheep/goat accounting for 16.7 percent and cattle/ water buffalo another 5.0 percent. The total large mammal remains (including unidentified animals) represent only 10.0 percent of the faunal assemblage, less than the total medium-sized mammalian remains of 21.7 percent. No pig bones were identified at Fort Diamond.

\section{DISCUSSION}

The results of the archaeological study presented here suggest that the sultan continued to have bountiful prestige goods even after Banten became a vassal state of the 
Dutch East India Company in 1682, but consumption of prestige goods gradually declined toward the end of the sultanate in 1813. Evidence of quotidian activities at the court most likely reflects the sultan's continued connections with and interest in local and regional trade networks. Our data suggest that royal residents used more imported fine-paste kendi than lower quality ware produced at local kilns, although they used both types. Potters in Banten made an extra effort to emulate hard-bodied, fine-paste kendi, but the quality of their products was limited by their only having access to locally available clay, which was unsuitable for producing fine-paste ware.

The preference for imported ware over locally produced kendi and the mixed use of both types persist at Surosowan Palace from the seventeenth to the early nineteenth century, although the overall number of kendi declines at the core area in the eighteenth century. Through the early nineteenth century, the sultan appears to have maintained his access to imported high-quality kendi, albeit on a smaller scale, as well as products made by local artisans. These data underscore the significance of Southeast Asian trade and material culture to Bantenese elites throughout the vassal period. The data also expand the scope of foreign prestige goods from Chinese porcelain to include imported, fine-paste Southeast Asian ware.

Similarly, the results of our study on imported porcelain demonstrate the initial abundant consumption of high-quality porcelain and its decline over time at the palace sites. The higher density of Jingdezhen porcelain in the seventeenth- to eighteenth-century assemblage compared to that of the eighteenth to early nineteenth century at the Surosowan Palace core area is particularly significant, given that the earlier assemblage probably covers the time period when Jingdezhen production was curtailed in China due to warfare and maritime trade bans. This distribution suggests copious consumption of Jingdezhen porcelain in the court of Banten, relative to its overall availability in the overseas market. Jingdezhen porcelain, however, declines over time at the palace sites and is replaced by Fujian/Guangdong ware.

By the beginning of the eighteenth century, Jingdezhen porcelain may no longer have served as a good indicator of prestige goods in Banten. Jingdezhen products probably lost their allure for the elite as they had become more readily available after Jingdezhen factories reopened to the export market in the late seventeenth to early eighteenth century (Sakai 2002a:101-102). It is important to note that European ceramics such as Delftware from the Netherlands did not replace Jingdezhen as prestige ware in Banten, however. This implies that European influence on the material culture of the sultan's private domain was limited.

Ming-period porcelain from Fujian/Guangdong perhaps serves as a better indicator of Banten's prestige material culture than Jingdezhen ware. This type of porcelain is most concentrated at the Surosowan Palace core area, particularly from the seventeenth to eighteenth century. The sultan and his court appear to have continued to use Fujian/Guangdong heirloom ware from the Ming period, at a time when this type of ware was favored in the Southeast Asian market and Chinese porcelain was scarcer and carried higher prestige value than it did during and after the late seventeenth century (Vainker 1991:145-146). The Bantenese elites may have emulated the past glories associated with Chinese porcelain from the earlier time period. The Ming-period Fujian/Guangdong porcelain declines from the seventeenth to the early nineteenth century at the palace core area, coinciding with the passage of time from purchase to presumed breakage of porcelain, which left fewer pieces of Ming porcelain to be used (or discarded) by succeeding generations. Overall, the results of our study suggest that 
the sultan and his court used more heirloom Ming and Jingdezhen porcelain than did the VOC garrison stationed at Fort Diamond, but the scale of palace use declined in the eighteenth to early nineteenth century.

Chinese production dominates the porcelain excavated both at the Bantenese and VOC sites. These data suggest the presence of active China trade and imply that networks of Chinese merchants made these products available both to the Bantenese and Europeans throughout the periods discussed here. We often rely on official European documents to reconstruct early modern trade in Southeast Asia. However, our archaeological data on Chinese porcelain and Southeast Asian fine-paste kendi reveal important aspects of regional trade that has hitherto been underdocumented. Particularly its multinational aspects provide insight into the complexity and dynamism of Island Southeast Asian trade.

The large number of small bowls relative to plates reveals a traditional preference amongst Bantenese for vessel forms. This pattern is slightly reversed at the Surosowan Palace core area in the eighteenth- and early nineteenth-century assemblage, when it becomes more similar to the distribution at Fort Diamond. This result may signal a change in eating habits among Bantenese elites. As they hosted more European guests at Surosowan Palace, they may have adopted a European style of dining that emphasizes using plates more than small bowls. However, since Bantenese elites appear to have favored large Chinese porcelain plates as early as the sixteenth century (Sakai 2002a:101-102), a more detailed porcelain analysis would be required to test this hypothesis.

The consumption of the meat of large mammals, especially the culturally prestigious water buffalo and cows, demonstrate a differentiated distribution similar to kendi and Chinese porcelain. Water buffalo and cattle bones are most concentrated at the Surosowan Palace dumping area, where presumably animals were butchered for palace consumption and some parts discarded. Complemented by ethnographic and textual evidence, these data indicate that the politically subordinated Bantenese elites commanded a meat-based diet of higher economic value than that of the politically dominant Dutch. This consumption pattern, however, shifts toward a fowl- and fishoriented diet by the eighteenth century, suggesting that both the power and wealth of the sultan declined toward the end of the sultanate.

The lack of pig bones excavated at Fort Diamond contrasts with the copious consumption of pork recorded at non-Islamic VOC sites, such as the Dejima VOC trading post in Japan (Nishinakagawa 2008:113-116). However, an eighteenth-century list of required provisions for VOC ships bound for Asia hints that the Dutch garrison may have eaten deboned salted pork in Banten (Bruijn et al. 1987:214-215). Our result only suggests that VOC employees in Banten may have refrained from ostentatiously butchering and consuming pork in consideration of the Islamic practice of forsaking pork.

The results of our archaeological research at Surosowan Palace suggest that the decline of the sultanate was more gradual than was concluded by earlier scholars. Archaeologists interpreted changes in monumental architecture in tandem with major historical events as indicative of a rapid demise in the power of the sultan. We find, however, that the sultan maintained a bountiful consumption of prestige goods such as imported fine-paste kendi, Ming-period Chinese porcelain, and water buffalo meat, for some time after the VOC stripped him of his pepper trade monopoly and 
diplomatic authority in the 1680s. The sultan appears to have largely preserved a traditional local and regional food-related material culture, rather than adopting a European diet or dining paraphernalia. Our results indicate that the audience he targeted for conspicuous displays of consumption probably consisted of indigenous allies and nobility rather than European newcomers. The competitive internal and external political landscape, often observed in early modern Island Southeast Asia, may have required the sultan to maintain the sultanate's allies while keeping rivals at bay.

This aspect of everyday material culture contrasts with the monumental architecture driven by the Dutch that emerged at the onset of Dutch political and economic interventions in the sultanate. Thus, a two-tiered process occurred in the sultan's power relationships. One tier (such as monumental architecture) operated in the permanent and public domain, where the sultan continued to convey political messages to his people. Another tier operated in the temporary and private domain of smallscale feasting and ceremonies held in the Banten court; such rituals maintained the sultan's traditional prestige material culture. However, if the sultan's independent ability to form alliances, so central to his strategies for negotiating power, became largely diminished, if not completely quashed by the VOC, it would have contributed to undermining the sultan's power. This would coincide with the overall decline in his feasting and ceremonial activities and associated prestige goods observed in the archaeological record.

\section{ACKNOWLEDGMENTS}

We thank the National Science Foundation (Doctoral Dissertation Improvement Grant No. 1332996), Boston University (Gabel Scholarship and Long-term Graduate Research Abroad Fellowship), the American Philosophical Society (Lewis and Clark Fund for Exploration and Field Research), the Henry Luce Foundation (support for East and Southeast Asian Archaeology at Boston University), Lee Foundation, and an anonymous donor for their funding support of this project. Many thanks to Robert Murowchick, Mary Beaudry, John Marston, Andrea Berlin, John Miksic, Koji Ohashi, Takashi Sakai, Kathryn Ness, and anonymous reviewers for their invaluable advice. This article was originally presented as a paper at the "Early Navigation in the Asia-Pacific Region: A Maritime Archaeological Perspective" Symposium at the Harvard-Yenching Institute, Cambridge, MA.

\section{NOTES}

1. Original etching may be seen at: Plattegrond van Bantam, 1596. Artist unknown, 1597-1598. Etching on paper. Rijksmuseum (website), Amsterdam. http://hdl.handle.net/10934/RM0001.COLLECT. 449945.

2. Our excavations represent only a fraction of the entire palace site, hence our incorporation of historical European and indigenous texts and ethnographic sources to supplement the archaeological record.

3. Hoping to obtain direct evidence of plant-based foods, we floated excavated sediment to recover macroplants and collected soil samples to extract phytoliths (silica remains of plants). The results of these efforts were too limited to be of use in this study, however. The number of recovered macroplants was insufficient to perform a statistically significant analysis and phytoliths of edible plants recovered from cached vessels were difficult to distinguish from those of the surrounding vegetation (Ueda 2015 : 236-237).

4. Although Sejarah Banten does not explicitly describe these people, they were most likely indigenous captives who had been forced into labor. For the Southeast Asian tradition of slavery, see Junker (1999) and Reid (1988, 1:129-136); for slavery specific to Dutch Indonesia, see Jones (2010) and Taylor (2009). 
5. Fujian/Guangdong ware was also carried by Dutch ships to VOC garrison sites in the Colonial Cape in South Africa (Charleston 1965: 17; Lucas 2004:36-38).

6. An anglo cooking stove can be seen in the lower right corner of an etching depicting the first Dutch expedition to Banten in 1596. Bazaar van Bantam, 1596 [Banten's market, 1596], 1597-1598. Artist unknown. Etching and engraving on paper. Rijksmuseum (website), Amsterdam. http://hdl.handle. net/10934/RM0001.COLLECT.449946.

\section{REFERENCES CITED}

\section{Adhyatman, Sumarah}

1981 Keramik kuna yang ditemukan di Indonesia, berbagai penggunaan dan tempat asal [Antique ceramics found in Indonesia, various uses and origins]. Jakarta: Himpunan Keramik Indonesia.

1990 Antique Ceramics Found in Indonesia: Various Uses and Origins. Jakarta: Ceramic Society of Indonesia.

ANDAYa, Barbara Watson

1992 Political development between the sixteenth and eighteenth centuries: From early times to c. 1800, in The Cambridge History of Southeast Asia, vol. 1: 402-459, ed. Nicholas Tarling. Cambridge: Cambridge University Press.

Ardika, Wayan, and Peter Bellwood

1991 Sembiran: The beginnings of Indian contact with Bali. Antiquity 65(247) :221-232.

Ardika, Wayan, Peter Bellwood, Made Sutaba, and Kade Citha Yuliati

1997 Sembiran and the first Indian contacts with Bali: An update. Antiquity 71(271): 193-195.

Bellwood, Peter

2005 First Farmers: The Origins of Agricultural Societies. Malden: Blackwell Publishers.

Blanton, Richard E., Gary M. Feinman, Stephen A. Kowalewski, and Peter N. Peregrine

1996 A dual-processual theory for the evolution of Mesoamerican civilization. Current Anthropology $37(1): 1-14$.

BOOMgAard, P.

2007 Southeast Asia: An Environmental History. Santa Barbara: ABC-Clio.

Boontharm, Dinar

2003 The Sultanate of Banten AD 1750-1808: A Social and Cultural History. Ph.D. diss. University of Hull, Kingston upon Hull.

Bosma, Ulbe, and R. Raben

2008 Being "Dutch" in the Indies: A History of Creolisation and Empire, 1500-1920. Singapore and Athens: National University of Singapore Press and Ohio University Press.

Bruijn, Jacobus R., F. S. GaAstra, and I. Schöffer

1987 Dutch-Asiatic Shipping in the 17th and 18th Centuries, vol. I. The Hague: Nijhoff.

Calo, Ambra, Bagyo Prasetyo, Peter Bellwood, James W. Lankton, Bernard Gratuze, Thomas Oliver Pryce, Andreas Reinecke, Verena Leusch, Heidrun Schenk, Rachel Wood, Rochtri A. Bawono, I. Dewa Kompiang Gede, Ni L. K. Citha Yuliati, Jack Fenner, Christian Reepmeyer, Cristina Castillo, and Alison K. Carter

2015 Sembiran and Pacung on the north coast of Bali: A strategic crossroads for early trans-asiatic exchange. Antiquity 89(344):378-396.

Charleston, R. J.

1965 English Porcelain, 1745-1850. London: E. Benn.

Chau, Ju-Kua (a.K.A. Zhao Rugua) 趙汝适

1911 Chau Ju-kua: His Work on the Chinese and Arab Trade in the Twelfth and Thirteenth Centuries, trans. F. Hirth and W. W. Rockhill. St. Petersburg: Printing Office of the Imperial Academy of Sciences.

Dias, M. Isabel, M. Isabel Prudêncio, Maria Antónia Pinto de Matos, and A. Luisa Rodrigues

2013 Tracing the origin of blue and white Chinese porcelain ordered for the Portuguese market during the Ming dynasty using INAA. Journal of Archaeological Science 40(7) : 3046-3057.

Dietler, Michael

1990 Driven by drink: The role of drinking in the political economy and the case of Early Iron Age France. Journal of Anthropological Archaeology 9(4):352-406. 
2001 Theorizing the feast: Ritual of consumption, commensal politics, and power in African contexts, in Feasts: Archaeological and Ethnographic Perspectives on Food, Politics, and Power: 65-114, ed. Michael Dietler and Brian Hayden. Washington D.C.: Smithsonian Institution Press.

DJAJADININGRAT, HOESAIN

1983 Tinjauan keritik tentang Serjarh Banten [Overview of Sejarah Banten]. Jakarta: Koninklijk Institut voor Taal.

Duco, Don H.

1987 De Nederlandse Kleipijp: Handboek voor dateren en determineren [The Dutch clay pipes: Handbook for dating and identifications]. Leiden: Stichting Pipenkabinet.

Edwards McKinnon, Edmund

1984 Kota Cina: Its Context and Meaning in the Trade of Southeast Asia in the Twelfth to Fourteenth Centuries. Ph.D. diss. Cornell University, Ithaca.

ENG-LeE, SeOK Chee

1984 Introduction, in Kendis: 1-19. A Guide to the Collections: National Museum Singapore. Singapore: National Museum of Singapore.

FANG, LILI 方李莉

2002 Jingdezhen min yao 景德鎭民窑 [Jingdezhen private kilns]. Beijing 北京: Ren min mei shu chu ban she 人民美术出版社.

Feinman, Gary M., Kent G. Lightfoot, and Steadman Upham

2000 Political hierarchies and organizational strategies in the Puebloan Southwest. American Antiquity $65(3): 449-470$.

Fryke, Christopher, And Christopher Schweitzer

1700 A Relation of Two Several Voyages Made into the East-Indies by Christopher Fryke, Surg. and Christopher Schewitzer [sic]. London: D. Brown, S. Crouch, J. Knapton, R. Knaplock, J. Wyate, B. Took, and S. Buckley.

Fujian Sheng Bo wu guan 福建省博物馆 [Fujian Provincial Museum]

1997 Zhangzhou yao: Fujian Zhangzhou di qu Ming Qing yao zhi diao cha fa jue bao gao zhi yi 漳州窑: 福建漳州地区明清窑址调查发掘报告之 [Zhangzhou kilns: Excavation report of Ming-Qing kiln sites in Zhangzhou, Fujian]. Fuzhou 福州: Fujian ren min chu ban she 福建人民出版社.

GeERTZ, ClifFord

1973 The Interpretation of Cultures: Selected Essays. New York: Basic Books.

1980 Negara: The Theatre State in Nineteenth-Century Bali. Princeton: Princeton University Press.

GeErTz, Hildred

1961 The Javanese Family: A Study of Kinship and Socialization. New York: Free Press of Glencoe.

Guillot, Claude

1993 Banten in 1678. Indonesia 57:89-114.

Guillot, Claude, Hasan Muarif Ambary, and Jacques Dumarçay

1990 The Sultanate of Banten. Jakarta: Gramedia.

Guo, Zhengdong

2011 Petrographic analysis of earthenware from Panjunan site, Banten Lama, Indonesia. Unpublished report submitted to the National Research Center of Archaeology of Indonesia, Jakarta.

HARRISSON, BARBARA

1979 Swatow, in Het Princessehof: The Analysis of a Museum Collection of Chinese Trade Wares from Indonesia: 131. Leeuwarden: Gemeentelijk Museum Princessehof.

Heydt, Johann WOLFFGang

1744 Plan oder Grundriss des Königs und edl. Compagnies Fortresse in Bantam von den In[n]ländern Talm genannt; Kartenmaterial [Plan or layout of the King's and the Company's fortresses in Bantam called by Talm residents; maps] [map dated 1739], in Allerneuester geographisch- und topographischer Schau-platz, von Africa und Ost-Indien, oder ausführliche und wahrhafte Vorstellung und Beschreibung, von den wichtigsten der Holländisch-Ost-Indischen Compagnie in Africa und Asia zugehörigen Ländere, Küsten und Insulen, in accuraten See- und Land-Karten, nicht weniger der darin-befindlichen Städte nebst ... einem Anhang oder historischer Beschreibung der Reise des Vefassers von Holland nach Ost-Indien [Very latest geographical and topographical exhibitions of Africa and East Indies, or detailed and truthful presentation and description of the most important land, coasts, and islands belonging to Dutch East India Company in Africa and Asia in accurate land and maritime maps]: 109. Willhermsdorff: Tetschner. Theatrum- 
Literatur der Frühen Neuzeit collection, Herzog August Bibliothek Wolfenbütteler. URL: http://diglib.hab.de/drucke/cd-2f-3/start.htm.

Hong Kong Urban Council 香港市政局, Hong Kong Museum OF History 香港歴史博物館, GuAngZhou Museum 廣州博物館, AND The Guangdong Provincial Museum 廣東省博物館

1996 Nanhai hai shang jiao tong mao yi er qian nian 南海海上交通贸易二千年 [The maritime silk route: 2000 years of trade on the South China Sea, 23rd January-28th April 1996]. Hong Kong: Hong Kong Urban Council.

IKuta, Shigeru 幾多滋 AND Shibusawa Motonori 渋沢元則

1981 Hautoman Fan Nekku: Higasi Indo shotōe no kōkai ハウトマンファン ネック 東インド諸島へ の航海 [Annotated translation of De Eerste Schipvaart der Nederlanders naar Oost-Indië onder Cornelis de Houtman (The first ship to sail to the Dutch East Indies under Cornelis de Houtman) 1595-1597, I, Den Haag, 1915]. Tokyo 東京: Iwanami shoten 岩波書店.

JONES, ERIC

2010 Wives, Slaves, and Concubines: A History of the Female Underclass in Dutch Asia. DeKalb: Northern Illinois University Press.

JUNKER, LAURA LEE

1998 Integrating history and archaeology in the study of contact period Philippine chiefdoms. International Journal of Historical Archaeology 2(4) : 291-320.

1999 Raiding, Trading, and Feasting: The Political Economy of Philippine Chiefdoms. Honolulu: University of Hawai'i Press.

2001 The evolution of ritual feasting systems in prehistoric Philippine chiefdoms, in Feasts: Archaeological and Ethnographic Perspectives on Food, Politics, and Power: 267-310, ed. Michael Dietler and Brian Hayden. Washington D.C.: Smithsonian Institution Press.

2004 Political economy in the historic period chiefdoms and states of Southeast Asia, in Archaeological Perspectives on Political Economies: 223-251. ed. Gary M. Feinman and Linda M. Nicholas. Salt Lake City: University of Utah Press.

2010 Trade Competition, Conflict, and Political Transformations in Sixth- to Sixteenth-Century Philippine Chiefdoms. Honolulu: University of Hawai'i Press.

Kerr, Rose, AND Nigel WoOd

2004 Science and Civilisation in China, vol. 5: Chemistry and Chemical Technology, part 12: Ceramic Technology. Cambridge: Needham Research Institute and Cambridge University Press.

LODEWYCKSZ, WILLEM

[1598] Om de Zuid de eerste schipvaart naar Oost-Indië onder Cornelis de Houtman, 1595-1597 [To the

1997 south: The first ship to sail to the Dutch East Indies under Cornelis de Houtman, 1595-1597], trans. V. D. Roeper and Diederick Wildeman. Nijmegen: SUN.

LuCAS, GAvin

2004 An Archaeology of Colonial Identity: Power and Material Culture in the Dwars Valley, South Africa. New York: Kluwer Academic/Plenum Publishers.

Ma, Hongjiao, Jian Zhu, Julian Henderson, and Naisheng Li

2012 Provenance of Zhangzhou export blue-and-white and its clay source. Journal of Archaeological Science 39(5) : 1218-1226.

Mackenzie Private Collection

1816 Short history of Bantam, in Mackenzie Private Collection: Papers Relating Chiefly to Java and the Dutch East Indies, vol. 86:27-63. London: The British Library.

Medley, Margaret

1976 The Chinese Potter: A Practical History of Chinese Ceramics. New York: Scribner.

Michrob, Halwany

1982 The Archaeological Sites-Old Banten (West Java) Indonesia: A Preliminary Report of the Restoration and the Preservation on the Urban Sites in Old Banten. Jakarta: Directorate of Protection and Development of Historical Archaeological Heritage Department of Education and Culture.

Miksic, John N.

1979 Archaeology, Trade and Society in Northeast Sumatra. Ph.D. diss. Cornell University, Ithaca.

1989 Archaeological studies of style, information transfer and the transition from Classical to Islamic periods in Indonesia. Journal of Southeast Asian Studies 20(1): 1-10.

2013 Singapore and the Silk Road of the Sea, 1300-1800. Singapore: National University of Singapore Press. 
Morimura, Kenichi 森村健一

1995 Fukkenshō shōshū yōkei seika gosai, ruriji no hennen 福建省漳州窑系青花五彩瑠璃地の編年 [Typology of blue and white, wucai, and blue under-glazed ware from Zhangzhou, Fujian]. Osaka fu maizōbunkazai kyōkai kenkyū kiyō 大阪府埋蔵文化財協会硏究紀要 [Bulletin of Osaka Prefecture Cultural Properties Association] 3:363-372.

Muhaimin, Abdul Ghoffir

2006 The Islamic Traditions of Cirebon Ibadat and Adat among Javanese Muslims. Canberra: Australian National University EPress.

Nishinakagawa, Hayao 西中川駿

2008 Dejima Oranda shōkan ato (Heisei 13, 14, 15 nendo chōsa) shutsudo no dōbutsu itai 出島阿 蘭陀商館跡 (平成 13,14, 15 年度調査) 出土の動物遺体 [Dejima Dutch archaeological site (excavations in 2001, 2002, and 2003): Faunal remains], in Kunishitei Dejima Oranda shōkan ato: Kapitan heya ato hoka nishigawa kenzōbutsugun hakkutsu chōsa hōkokusho 国指定出島阿蘭陀 䒽館跡：カピタン部屋跡ほか西側建造物群発掘調査報告書 [Nationally designated historic site of the Dutch factory in Dejima: Excavation report of Chief Factor's residence and other Western buildings], vol. 2:110-121. Nagasaki: Nagasaki City Board of Education.

Nö̈L Hume, IVOR

1970 A Guide to Artifacts of Colonial America. New York: Knopf.

OHashi, Koji 大橋孝二

2004 Umi wo watatta tojiki 海を渡つた陶磁器 [Ceramics that traveled across the sea]. Tokyo 東京: Yoshikawa Kōbunkan 吉川弘文館.

Ohashi, Koji 大橋康二 And Sakai TAKashi 坂井隆

1999 Indonesia Banten iseki shutsudo no tōjiki インドネシア・バンテン遺跡出土の陶磁器 [Ceramics from the site of Banten, Indonesia]. Kokuritsu rekishi minzoku hakubutsukan kenkyū hokkokusho 国立歴史民族博物館㸴究報告書 [Bulletin of the National Museum of Japanese History] 82:47-94.

ONGHOKHAM

2003 The Thugs, the Curtain Thief, and the Sugar Lord: Power, Politics, and Culture in Colonial Java. Jakarta: Metafor Pub.

Ота, Atsushi

2006 Changes of Regime and Social Dynamics in West Java: Society, State, and the Outer World of Banten, 1750-1830. Leiden: Brill.

Pires, TOMÉ

[1515] Java, in The Suma Oriental of Tomé Pires: An Account of the East, from the Red Sea to China,

2005 Written in Malacca and India in 1512-1515; and, The Book of Francisco Rodrigues: Pilot-major of the Armada that Discovered Banda and the Molucca: Rutter of a Voyage in the Red Sea, Nautical Rules, Almanack and, Maps, Written and Drawn in the East before 1515:166-200. New Delhi: Asian Educational Services.

Pudjiastuti, Titik

2000 Sadjarah Banten: suntingan teks dan terjemahan disertai tinjauan aksara dan amanat [History of Banten: Edited texts and translation with review of scripts and addresses]. Ph.D. diss. Universitas Indonesia, Jakarta.

Raffles, Thomas Stamford

1830 The History of Java, 2 vols. London: J. Murray.

REID, ANTHONY

1988 Southeast Asia in the Age of Commerce, 1450-1680, 2 vols. New Haven: Yale University Press.

1992 Economic and social change, c. 1400-1800, in The Cambridge History of Southeast Asia: 460-507, ed. Nicholas Tarling. Cambridge and New York: Cambridge University Press.

1993 Southeast Asia in the Early Modern Era: Trade, Power, and Belief. Ithaca and London: Cornell University Press.

RiCKLEFS, M. C.

1981 A History of Modern Indonesia since c. 1200. Stanford: Stanford University Press.

Rouffaer, Gerret Pieter, and Jan Willem Ijzerman

1915 De eerste schipvaart der Nederlanders naar Oost-Indië onder Cornelis de Houtman, 1595-1597; journalen, documenten en andere bescheiden [The first ship to sail to the Dutch East Indies under Cornelis de Houtman, 1595-1597; journals, documents and other records]. 's-Gravenhage (The Hague): Martinus Nijhoff. Digital copy available at: https://archive.org/ details/deeersteschipvaa01 rouf. 
SAKAI, TAKASHI 坂井隆

1992a Nankai no suichū-Indoneshia no kundi 南海の水注：インドネシアのクンディ [Water jars of the southern sea-Indonesian kendi] in Kodai tansō 古代探叢 [Monograph on antiquities] 3:596-616, ed. H. Takiguchi. Tokyo: Waseda Daigaku Shuppan 早稲田大学出版.

$1992 b$ Kundi suichū no kigen一keishikigakuteki kōsatsu no shiron クンデイ水注の起源：形式学的 考察の私論 [The origin of kendi: Investigation of typology]. Tozai kaijyo kōryushi kenkyū 東西 海上交流史研究 [Study Group for East-West Maritime Relations] 2:30-61.

$2002 a$ Kōshi kokka Banten to tōjiki bōeki 港市国家バンテンと陶磁器貿易 [Banten, a port city state and its ceramic trade]. Tokyo 東京: Dōseisha 同成社.

2002 Tōnan Ajia guntōbu no tōjiki shōhisha 東南アジア群島部の陶磁器諸費者 [Consumers of ceramics in the Southeast Asian islands]. Kokuritsu rekishi minzoku hakubutsukan kenkyū hōkokusho 国立歴史民族博物館研究報告書 [Bulletin of the National Museum of Japanese History] 94:159-229.

Stark, Miriam T.

2014 The archaeology of early modern South East Asia, in The Oxford Handbook of Historical Archaeology: 1-12, ed. James Symonds and Vesa-Pekka Herva. Oxford Handbooks Online. Oxford: Oxford University Press. URL: http://www.oxfordhandbooks.com/view/10.1093/oxfordhb/ 9780199562350.001.0001/oxfordhb-9780199562350-e-48.

Stavorinus, Johan Splinter

1798 East Indies: The Whole Comprising a Full and Accurate Account of All the Present and Late Possessions of the Dutch in India, and at the Cape of Good Hope, vol. 1, trans. S. H. Wilcocke. London: G. G. and J. Robinson.

Sulendraningrat, P. S.

1978 Beralihnya pulau jawa dari agama sanghyang kepada agama islam [Change of religion in Java from Sanghyang to Islam]. Cirebon: Pengguron Caruban Krapyak Kaprabon.

TALENS, JOHAN

1993 Ritual power: The installation of a king in Banten, West Java, in 1691. Bijdragen tot de Taal-, Land-en Volkenkunde [Journal of the Humanities and Social Sciences of Southeast Asia (BKI)] $149(2): 333-355$.

TAmbiah, Stanley Jeyaraja

1976 World Conqueror and World Renouncer: A Study of Buddhism and Polity in Thailand against a Historical Background. Cambridge: Cambridge University Press.

TAYLOR, JeAn GeLman

2009 The Social World of Batavia: Europeans and Eurasians in Colonial Indonesia. Madison: University of Wisconsin Press.

UEDA, KAORU

2011 Petrographic analysis of earthenwares from Banten Lama in northwestern Java, Indonesia. Unpublished report submitted to the National Research Center of Archaeology of Indonesia, Jakarta.

2013 Southeast Asian fine-paste ware: Petrographic analyses of ceramic sherds from southern Thailand, Sumatra, and Java. Unpublished report submitted to the National Research Center of Archaeology of Indonesia, Jakarta.

2015 An Archaeological Investigation of Hybridization in Bantenese and Dutch Colonial Encounters: Food and Foodways in the Sultanate of Banten, Java, 17th-Early 19th Century. Ph.D. diss. Department of Archaeology, Boston University.

Ueda, Kaoru, Sonny Wibisono, and Zhengdong Guo

2012 The petrographic analysis on earthenwares excavated at 17th- to 18th-century Banten Lama, Java, Indonesia: The Sultan's power negotiation amid European colonialism. Unpublished paper presented at the 77th Annual Meeting of Society for American Archaeology, 18-22 April 2012, Memphis.

VAINKER, S. J.

1991 Chinese Pottery and Porcelain: From Prehistory to the Present. New York: George Braziller.

VAN BRuinessen, Martin

1995 Shari'a court, Tarekat and Pesantren: Religious institutions in the Sultanate of Banten. Archipel $50: 165-200$. 
VOC (Vereenigde Oostindische Compagnie) [Dutch East India Company]

1733 Rolle van persoonen European, en islandse persoonen, als in de attaoqye der Baliers op der 4 Julij de ses zaars, gesneuvelt, engequest in namentlijk [Roster of European and Native (Island) Personnel who were killed or injured during the attack of Balinese on 4 July 1733]. VOC 04.02.01 7687 fol. 100-101. The Hague: The National Archives.

1780 Copij Bantamse afgaande gemeene en aparte brieven aan haar hoog edelhedens te Batavia voor Nederland van 2 Januarij tot en met 31 December 1780 (ontvangen anno 1780). [Copy of Bantam report and previous letters to the High Council in Batavia of the Netherlands 2 January to 31 December 1780 (received in the year of 1780)]. VOC 1.04.02 7727 Bantam fol. 11-144. The Hague: The National Archives.

WADE, GEOFF

2009 An early age of commerce in Southeast Asia, 900-1300 CE. Journal of Southeast Asian Studies 40(2): 221-265.

WiBISONO, SONNY

1994 Poterie [Pottery], in Banten avant l'Islam: Etude archeologique de Banten Girang (Java-Indonesie) 932-1526 [Banten before Islam: Archaeological study of Banten Girang (Java, Indonesia) 932-1526]: 169-181, ed. Claude Guillot, Lukman Nurhakim, and Sonny Wibisono. Paris: Publications de l'École Française d'Extriême-Orient.

Wolters, O. W.

1982 History, Culture, and Region in Southeast Asian Perspectives. Singapore: Institute of Southeast Asian Studies.

\begin{abstract}
This article discusses the results of our archaeological research at an important global pepper-trading center located in west Java, Indonesia, to examine the sultan's power and the transition processes from the year 1682 when the Dutch East India Company effectively took political and economic control over the sultanate, until the official end of the Sultanate of Banten in 1813. Through the study of prestige goods and food used at the court, we critically explore power relationships in this early stage of colonialism. The results of our study suggest that European cultural influence was limited to the public domain and most aspects of the sultan's daily life largely remained unchanged. However, the changing political structure was one factor in the eventual decline of the sultan's power. The archaeological focus on foodways in the study presented here reveals a more nuanced understanding of these gradual political changes than has been suggested by previous archaeological research primarily based on monumental architecture and major historical events. KEYwORDs: colonialism, trade, Indonesia, foodways, prestige goods, Dutch East India Company.
\end{abstract}

